\title{
ACCOMMODATING DiscRiminAtion
}

\author{
Ashlie C. Warnick*
}

INTRODUCTION

\section{PART I: EMPLOYMENT-DISCRIMINATION LAWS AND PRIVATE RELIGIOUS}

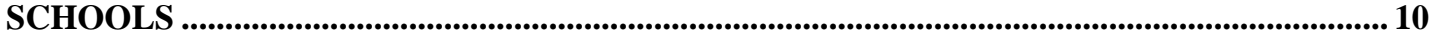

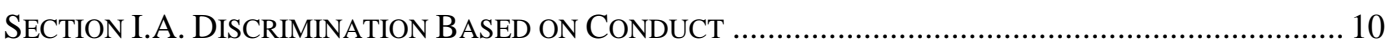

Section I.A.1: Conduct Concerning Groups Protected by Federal, State, or Local

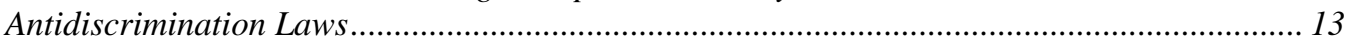

Section I.A.2: Religious Schools Conduct-Based Firings and Refusals-to-Hire Based on

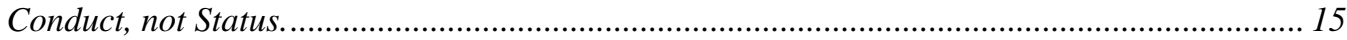

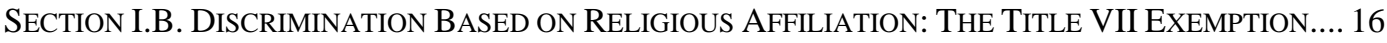

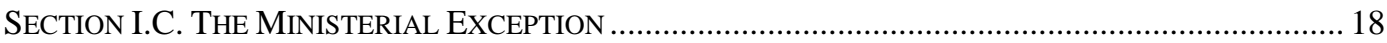

PART II: THE ESTABLISHMENT CLAUSE, RELIGIOUS FREEDOM, AND

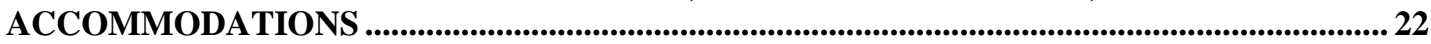

Section II.A. The Supreme Court's CATCh-All Establishment Clause TeSt ........................ 24

SECTION II.B. A NEW TEST FOR AsSESSING RELIGIOUS ACCOMMODATIONS ..................................... 30

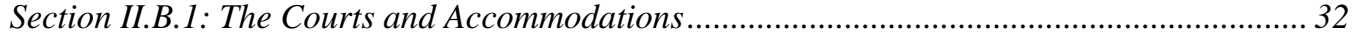

Section II.B.2: A New Test for Accommodations ...................................................................... 35

PART III: DOES GOVERNMENT MONEY CHANGE THE OUTCOME? ................................... 44

SECTION III.A: EMPLOYMENT DISCRIMINATION AND ENDORSEMENT ………………….................. 48

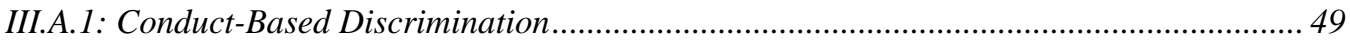

III.A.2: The Title VII Exemption for Religious Affiliation Discrimination .................................. 50

Section III.A.3: The Ministerial Exception .................................................................................. 51

SECTION III.B: LIMITATIONS ON ANTIDISCRIMINATION EXEMPTIONS ................................................ 52

PART IV: THE FREE EXERCISE CLAUSE, EMPLOYMENT ANTIDISCRIMINATION LAWS, AND RELIGIOUS SCHOOLS IN SCHOOL VOUCHER PROGRAMS......................... 54

SECTION IV.A: Two TyPes of FreE EXERCise CASES AND THE Ministerial EXCEPTION.............. 55

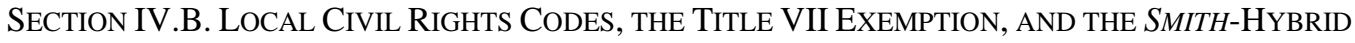

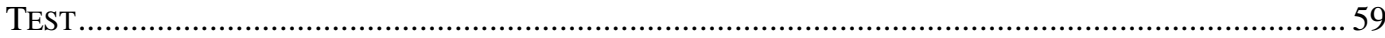

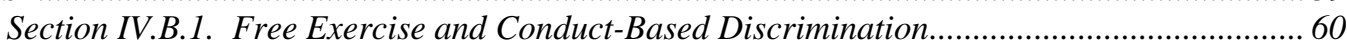

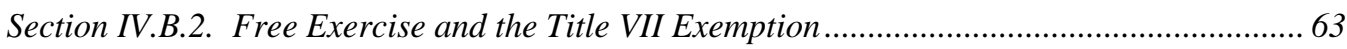

PART V: CONDITIONING PARTICIPATION ON RELINQUISHMENT ................................. 66

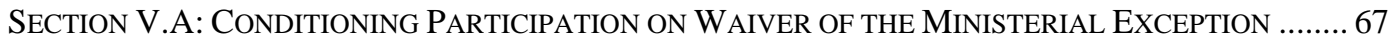

SECTION V.B: THE UnConstiTUTIONAL CONDITIONS DOCTRINE ...................................................... 68

\footnotetext{
* Ashlie C. Warnick, John M. Olin Fellow of Law, Yale Law School. B.A. 1993, University of Maryland, Baltimore County; M.A. (Economics) 1999, George Mason University; J.D. 2003, University of Michigan Law School; Ph.D. (Economics) 2004, George Mason University. I thank Kimberly Kefalas, Jonathon Macey, Ian Ayres, and the faculties at Creighton University Law School, the University of Tennessee College of Law, and the University of Toledo College of Law for their comments on an earlier version of this Article. Andrew McNiven (George Mason University, 2008) provided invaluable research assistance. Finally, I thank Robert Frommer for his support and editing assistance. Any errors, of course, are my own.
} 
Section V.B.1: Discretionary Government Benefit ................................................................... 71

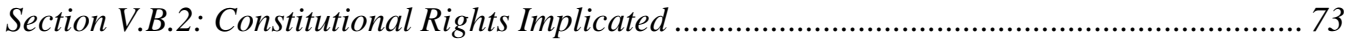

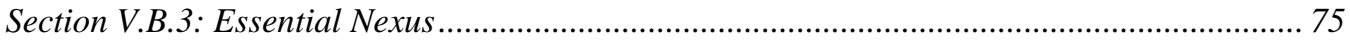

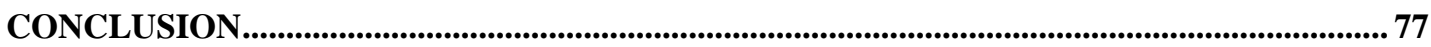




\section{INTRODUCTION}

In 2002, the Supreme Court found school-voucher programs ${ }^{1}$ that include religious schools constitutional. ${ }^{2}$ Once such a program is in place, ${ }^{3}$ it is unsettled whether state and local governments can place restrictions on the activities of religious schools as a condition on their participation. ${ }^{4}$ For example, the Court has not addressed whether state and local governments can require that the hiring

\footnotetext{
${ }^{1}$ While the term "school choice" encompasses many different arrangements, some including private schools and religious schools, the phrase "school-voucher programs" is narrower. For example, intradistrict public school choice allows students to attend other public schools within the school district, but not private schools. Vermont's and Maine's school choice programs provide students living in towns without public schools vouchers to attend private, but not religious, schools. Lastly, some authors include public charter schools and magnet schools under the "school choice" umbrella. To avoid this confusion of definitions, this Article refers to programs that provide tuition assistance for children to attend private, including religious, schools as "school voucher programs." Some schoolvoucher program proponents, however, dislike the term "voucher." "Voucher has become such a dirty word. Voucher is just a way of paying for something. We are talking about having families reassume the rights that have been taken away from them. It's not about vouchers. It's about freedom.” Michael Lynch, Higher Learning, REAson MAgAzine, June 2001, at 22 (quoting Ted Forstmann who, along with Sam Walton, formed the Children's Scholarship Fund which raised \$200 million for private school scholarships for low-income children). See also Amy Gutmann, Assessing Arguments for School Choice: Pluralism, Parental Rights, or Educational Results?, in SCHOOL CHOICE: THE MoRAL DeBATE 127 (Alan Wolfe ed., 2003).
}

${ }^{2}$ Zelman v. Simmons-Harris, 536 U.S. 639 (2002). For an enjoyable history of the legal battles leading up to Zelman, see Clint Bolick, Voucher WARS: WAGing THE LEgal BatTLE Over SCHOOL CHOICE (2003).

${ }^{3}$ This Article does not address whether excluding religious schools from participating in a voucher program would violate the Free Exercise Clause. For more information, see Locke v. Davey, 540 U.S. 712 (2004) (upholding a Washington program that prohibited higher-education tuition vouchers for religious instruction); Anderson v. Town of Durham, 895 A.2d 944, 952 (Me. 2006) (upholding Maine's school-voucher program that excludes religious schools); Thomas [C.] Berg, Vouchers and Religious Schools: The New Constitutional Questions, 71 U. Cin. L. REV. 151 (2003) (pre-Locke and Anderson analysis); Thomas C. Berg \& Douglas Laycock, The Funding of Religious Institutions in Light of Locke v. Davey: The Mistakes in Locke v. Davey and the Future of State Payments for Services Provided by Religious Institutions, 40 TUlSA L. ReV. 227 (2004); Matthew Gaus, Note, Locke v. Davey: Discretion, Discrimination, and the New Free Exercise, 54 KAN. L. REV. 553 (2006); Sarah Waszmer, Note, Taking It Out of Neutral: The Application of Locke's Substantial Interest Test to the School Voucher Debate, 62 WASH. \& LEE L. REV. 1271, 1275-1281 (2005).

${ }^{4}$ See, e.g., Gia Fonte, Note, Zelman v. Simmons-Harris: Authorizing School Vouchers, Education's Winning Lottery Ticket, 34 LOY. U. CHI. L.J. 479, 562 (2003). “The Court ... left one important question unanswered: What regulatory strings may the government attach to religious schools participating in voucher programs without violating the Constitution?” Id. 
practices of religious schools conform to local antidiscrimination laws. ${ }^{5}$ This open question has implications for the ultimate success of voucher programs.

Currently, voucher programs allowing students to attend religiously affiliated schools exist in Arizona, ${ }^{6}$ Florida, ${ }^{7}$ Georgia, ${ }^{8}$ Ohio, ${ }^{9}$ Utah, ${ }^{10}$ Milwaukee, Wisconsin, ${ }^{11}$ and the District of Columbia. ${ }^{12}$ Typically, low-income students attending underperforming public schools can qualify to participate in a voucher

5 "The courts have not fully addressed the validity of [religious schools' Title VII] exemption [for religious discrimination] where government-funded programs or positions are involved." David Saperstein, Public Accountability and Faith Based Organizations: A Problem Best Avoided, 116 HARV. L. Rev. 1353, 1393 (2003). See also Martha Minow, Should Religious Groups be Exempt from Civil Rights Laws?, 48 B.C. L. Rev. 781 (2007); Nadine Strossen, Religion and the Constitution: A Libertarian Perspective, 2005-06 CATO SuP. CT. REV. 7, 43 (2005/2006) (noting that "requiring religious institutions to adhere to [regulatory conditions], as a condition of funding, endangers the institutions' religious liberty”).

${ }^{6}$ Arizona has two school-voucher programs: one for special-needs children and one for foster-care children. ARIz. REV. STAT. §§ 15-891 - 891.06 (2007); ARIZ. REV. STAT. §§ 15-817 - 817.07 (2007).

${ }^{7}$ Florida's Opportunity Scholarship Program, which provided vouchers for all students in poorly performing public schools, was declared unconstitutional under the Florida Constitution based on a constitutional provision requiring uniformity among publicly funded schools. Bush v. Holmes, 919 So. 2d 392 (Fla. 2006). A similar program limited to special-needs students remains unchallenged. FLA. STAT. § 1002.39 (2007).

${ }^{8}$ Georgia’s program is limited to special-needs students. GA. CODE ANN. §§ 20-2110 - 2118 (2007).

${ }^{9}$ Originally available only in Cleveland schools, the Ohio legislature adopted the program statewide in 2005. OHIo Rev. CodE ANN. §§ 3310.01 - 3310.41 (2008) (statewide program); OHIO Rev. Code ANN. §§ 3313.974 - 3313.976 (2008) (Cleveland program).

${ }^{10}$ Utah's voucher program is limited to special-needs students. UTAH CoDE ANN. §§ 53A-1A-701 710 (2007). The implementation of a universal program was blocked by referendum in November 2007. See Dan Lips, School Choice: Policy Developments and National Participation Estimates in 2007-2008, Heritage Foundation Backgrounder No. 2102, Jan. 31, 2008, p. 6.

${ }^{11}$ The first school voucher program in the United States began in 1990. WIS. STAT. § 119.23 (2006).

${ }^{12}$ Rather than a local statute, the District of Columbia's voucher program resulted from an Act of Congress, the FY2004 District of Columbia Appropriations Bill. For the 2007-08 school year, over 1900 students were enrolled in the voucher program. Press release, D.C. School Choice Program Again Sets Record for Enrolled K-12 Students, Washington Scholarship Fund, Sept. 26, 2007, available at www.washingtonscholarshipfund.org/news/news/pr_09_26_07.html (last visited Feb. 27, 2008). 
program. ${ }^{13}$ These students receive tuition vouchers to defray or eliminate the cost of attending another school with a higher student-performance record. ${ }^{14}$ While secular private schools can participate, sectarian schools would likely be the schools of choice for participants because of the sheer predominance of religious schools. ${ }^{15}$

Proponents of school-voucher programs cite many theories about the need for these programs to provide alternatives to failing public schools. ${ }^{16}$ In addition to improving the public schools through competition for students ${ }^{17}$ and making schools

${ }^{13}$ The Arizona, Florida, Georgia, and Utah programs are limited to particular student populations, such as special-needs students or children in foster care. The Cleveland program allows low-income students in failing public school districts to use vouchers to pay tuition at private, including religious, schools or to attend participating public schools. The Milwaukee Parental Choice Program, the oldest voucher program in the country, and the District of Columbia program allow all children from lowincome families to attend private religious and non-religious schools. WIS. STAT. ANN. § 119.23 (West 1999). Participating schools must accept all income-eligible students. Id. The Cleveland Scholarship and Tutoring Program, the program considered by the Court in Zelman v. SimmonsHarris, awards scholarships to Cleveland students, with preference for low-income students, to attend private (religious and non-religious) schools or public schools in adjacent districts. OHIO REv. CoDE ANN. §§ 3313.974-3313.979 (Anderson 1999). At this time, no adjacent public schools participate in the program. Zelman v. Simmons-Harris, 536 U.S. 639, 647 (2002).

${ }^{14}$ See Wisc. Stat. AnN. §119.23 (West 1999); Ohio Rev. Code AnN. §§3313.974-3313.979 (Anderson 1999).

${ }^{15}$ See, e.g., 1 Thomas James \& Henry M. Levin, Comparing Public and Private Schools: INSTITUTIONS AND ORGANIZATIONS 34 (1988). According to the Institute for the Transformation of Learning at Marquette University, approximately $67 \%$ of parents participating in the Milwaukee Parental Choice Program chose to send their children to religious schools between 1998 and 2001. Id. In Cleveland's school voucher programs, 96\% of students attend religiously affiliated schools. Zelman v. Simmons-Harris, 536 U.S. 639, 647 (2002).

${ }^{16}$ See Amy Guttman, Assessing Arguments for School Choice: Pluralism, Parental Rights, or Educational Results, in School Choice: The Moral Debate 126 (Alan Wolfe ed., 2003); Terry M. Moe, Going Private, in Charters, Vouchers, ANd Public EduCATion 102, 102-04 (Paul E. Peterson \& David E. Campbell eds., 2001); Goodwin Liu \& William L. Taylor, School Choice to Achieve Desegregation, 74 FordHAM L. REV. 791, 805-808 (2005).

17 Caroline Hoxby, Rising Tide, Education Next, Winter 2001, at 69 (showing that in the Milwaukee Parental Choice Program, public "schools [that] fac[ed] the most potential competition from vouchers" had the best productivity response). See also Frederick M. Hess, et. al., Responding to Competition, in Charters, Vouchers, ANd Public Education 215 (Paul E. Peterson \& David E. Campbell eds., 2001). 
more accountable to parents, ${ }^{18}$ many advocates believe that school-voucher programs will provide parents with the opportunity to tailor their children's education. ${ }^{19}$ Schools that succeed at teaching students ${ }^{20}$ will continue in the program, while those that do not will rightfully be removed. The right formula of discipline, class-size, after-school tutoring, and teaching curricula will depend on each individual school and class. School-voucher programs allow parents to choose the school with the combination of factors that best suits their child. ${ }^{21}$ By allowing low-income students the opportunity to attend a school tailored to their needs, school-voucher programs will allow the experimentation ${ }^{22}$ necessary to determine what works best for each individual student. ${ }^{23}$

Opponents of school-voucher programs fall into two categories. First, some oppose voucher programs regardless of whether they include religious schools or

18 "School choice proponents want to ensure that the education system serves its 'customers' in order to earn its way. Currently, a public school is not accountable to the students enrolled in it or their parents. . . . In addition to making schools compete, school choice proponents want to make schools accountable to parents by making them the referees of this competition.” Nathan J. Diament, School Choice is the Right Choice, NATIONAL COUnCIL OF JeWISH Women Journal, Winter 1997, at 21.

${ }^{19}$ Id.

${ }^{20}$ At least one study shows improvement in standardized test scores among minorities enrolled in school-voucher programs. William G. Howell, et. al., Effects of School Vouchers on Student Test Scores, in Charters, Vouchers, AND Public Education 136, 144-45 (Paul E. Peterson \& David E. Campbell eds., 2001) (showing increased test scores for black students in private school-choice scholarship programs). See also George Will, Editorial, A New Approach to School Reform, Buffalo News, August 31, 2000, at 3C. But see John F. Witte, The Market Approach to Education: An ANAlysis OF AMERICA's First VOUCHER Program 114-15 (1999) (finding that most of the studies of the Milwaukee program show mixed results).

${ }^{21} I d$.

${ }^{22}$ In Hunter $v$. Regents of the University of California, the need for experimentation was used to justify race-based classifications for students in the UCLA Lab Schools. These schools are an experiment in schooling - the students are chosen because of characteristics, such as race or income, so that researchers can determine which teaching methods work best for each group of students and if there are any differences in the way one group of children learns compared with another group. 190 F.3d 1061 (9th Cir. 1999).

${ }^{23}$ See Goodwin Liu \& William L. Taylor, School Choice to Achieve Desegregation, 74 FordHAM L. REV. 791 (2005) (proposing a school-voucher program for economically-disadvantaged urban children to attend private schools and "middle-class suburban public schools"). 
not. ${ }^{24}$ They fear that using government funds to send children to private schools will drain money $^{25}$ or the most gifted students ${ }^{26}$ from public schools. The second group of opponents may support the voucher concept but want to exclude religious schools from the programs. ${ }^{27}$ One of the main concerns for this group is the separation of church and state. ${ }^{28}$ According to school-voucher opponents, government subsidies that go to religious schools are essentially the same as state sponsorship of religious education. ${ }^{29}$ The participation of religious schools in school-voucher programs could lead to increased tension between parents sending their children to religious schools

${ }^{24}$ See, e.g., EdD Doerr, ET. Al., The CASE Against School Vouchers 13-16 (1996) (including arguments that apply to religious schools participation and arguments that apply to any private schools participating in a voucher program).

${ }^{25}$ The National Education Association, the largest teachers union in the country, has "long opposed private school tuition vouchers - especially where funds for vouchers compete with funds for overall improvements in America's public schools.... [The NEA] oppose[s] alternatives that divert attention, energy, and resources from efforts to reduce class size, enhance teacher quality, and provide every student with books, computers, and safe and orderly schools.” NEA Issues in Education, Vouchers website, available at http://www.nea.org/vouchers/index.html (last visited Feb. 22, 2008).

${ }^{26}$ For an overview of the "skimming" debate, see Goodwin Liu \& William L. Taylor, School Choice to Achieve Desegregation, 74 FordHAm L. REV. 791, 817-821 (2005).

${ }^{27}$ See, e.g., JAMES G. DwYER, RELIGIOUS SCHOOLS V. CHILDREN’s Rights 14 (1998) (suggesting that some forms of religious education harm children); Steven K. Green, The Constitutionality of Vouchers After Mitchell v. Helms, 57 N.Y.U. ANN. SuRV. AM. L. 57, 57-64 (2000) (questioning the constitutionality of voucher programs that include private schools); Nadine Strossen, Religion and the Constitution: A Libertarian Perspective, 2005-2006 CATO SuP. CT. REV. 7, $42-43$ (2005/2006).

${ }^{28}$ See, e.g., Union of American Hebrew Congregations, Protecting the Walls Supporting Our Schools, The Reform Movement’s Campaign for Public Education 66th General Assembly, Dec. 5-9, 2001, at 1. Some scholars opposed to the inclusion of religious schools have offered an alternative: restricting religious schools participating in the programs to secular education. See, e.g., JAMES G. DWYER, VOUCHERS WITHIN REASON 147 (2002) (suggesting that religious schools in voucher programs should only be compensated for the secular education they provide); JOHN E. CHUBB \& Terry M. Moe, Politics, MARKets, \& AMERICA's Schools 219 (1990) (advocating a voucher program that includes religious schools but only if "their sectarian functions can be kept clearly separate from their educational functions”).

${ }^{29}$ See, e.g., Kathleen Sullivan, Religious Participation in Public Programs: Religion and Liberal Democracy, 59 U. CHI. L. REV. 195, 209-214 (1992). 
using vouchers and taxpayers whose funds are used to finance education in religions they oppose. ${ }^{30}$

Meanwhile, many supporters of religious education fear that government subsidization will harm religion ${ }^{31}$ by "kill[ing it] with kindness." 32 Religious schools could come to rely on government support rather than their followers. ${ }^{33}$ This will lead to "greater institutional interoperability and dependency, subject recipient institutions to increasing governmental oversight, and thereby begin to quash the independent spirit from the religious groups upon which society depends to counter relatively soulless government bureaucracies.”34

${ }^{30}$ For the typical divisiveness arguments, see Zelman v. Simmons-Harris, 536 U.S. 639, 715-717 (2002) (Souter, J., dissenting); id. at 717-726 (Breyer, J., dissenting); Respondent's Brief at 7-24, Zelman v. Simmons-Harris, 536 U.S. 639 (2002) (No. 00-1751).

${ }^{31}$ Including religious organizations in public programs "triggers sharp criticisms ... from those concerned that government aid may intrude on the autonomy and freedom of religious groups." Martha Minow, Public and Private Partnerships: Accounting for the New Religion, 116 HARV. L. REV. 1229, 1232 (2003). "[M]any advocates of religious freedom oppose vouchers because they fear that the government will require religious schools to 'water down' their religious character in order to receive public funding.” Gia Fonte, Zelman v. Simmons-Harris: Authorizing School Vouchers, Education's Winning Lottery Ticket, 34 Loy. U. CHI. L.J. 479, 563 (2003). See also Nicole Stelle Garnett \& Richard Garnett, School Choice, the First Amendment, and Social Justice, 4 TEX. REv. LAW \& POLI. 301, 339 (2000).

${ }^{32}$ Derek H. Davis, Mitchell v. Helms and the Modern Cultural Assault on the Separation of Church and State, 43 B.C. L. Rev. 1035, 1039 (2002). See also Nadine Strossen, Religion and the Constitution: A Libertarian Perspective, 2005-2006 CATO SuP. CT. REV. 7, $42-43$ (2005/2006).

${ }^{33}$ Id. at 1067. But see Eugene Volokh, Equal Treatment is Not Establishment, 13 Notre DAME J.L. EтHICs \& Pub. POL'Y 341, 354 (1999) (suggesting that "the risk of government pressure that leads some [religious schools] to abandon their religious obligations ... is as present under the existing system as under a school choice system”).

${ }^{34}$ Derek H. Davis, Mitchell v. Helms and the Modern Cultural Assault on the Separation of Church and State, 43 B.C. L. Rev. 1035, 1049 (2002). The Eagle Forum of Georgia, a Christian-based conservative organization, warned in a newsletter that "[b]ecause [government funding] brings ... religion-restricting government regulations, many ... religions ... know better than to hand over control of their social service ministries to the government. ... Government vouchers ... will just bring more government, not more liberty." Quoted in Nadine Strossen, Religion and the Constitution: A Libertarian Perspective, 2005-2006 CATO SuP. CT. REV. 7, 42 (2005/2006). 
Opponents of school-voucher programs share these same concerns in the context of charitable-choice programs. ${ }^{35}$ In that arena, several commentators have called for legislation that would condition participation in the program on adherence to employment-antidiscrimination laws. ${ }^{36}$ These scholars believe that participation by religious organizations in public programs should be predicated on foregoing exemptions from these laws. ${ }^{37}$

Similarly, several commentators suggest that a religious school's limited ability to discriminate in employment must be curtailed if they wish to participate in school-voucher programs. ${ }^{38}$ This threat may lead some schools to refuse to

${ }^{35}$ See, e.g., Frederick Mark Gedicks, A Two-Track Theory of the Establishment Clause, 43 B.C. L. REV. 1071, 1105-1106 (2002).

36 "Contract and voucher plans must have ... public strings attached and enforced through adequate oversight and monitoring." Martha Minow, Public and Private Partnerships: Accounting for the New Religion, 116 HARV. L. REV. 1229, 1261 (2003). "President Bush's promised expansion of faithbased social service initiatives is bogged down in questions about the extent to which (if at all) religious social service providers should be exempt from federal antidiscrimination laws in hiring their employees.” Frederick Mark Gedlicks, A Two-Track Theory of the Establishment Clause, 43 B.C. L. REV. 1071, 1105 (2002). Professor Gedlicks suggests that religious exemptions from antidiscrimination laws be limited to certain central positions. Id. at 1106 .

${ }^{37}$ Martha Minow, Public and Private Partnerships: Accounting for the New Religion, 116 HARV. L. REV. 1229, 1261 (2003) "Publicly subsidized schooling, health care, welfare, and social services must ... advance public values [including] freedom from exclusion or inferior treatment on the basis of race, national origin, ethnicity, language, gender, disability, religion, and increasingly, sexual orientation." Id. "[A] state can work with religious providers of welfare and social services only if the providers, like the state itself, refrain from violating state and local antidiscrimination employment law...." Id.

38 "Once the public begins to finance religious education, the regulatory concerns about design of curriculum, admissions, policy, and employment decisions will surface with a vengeance.” Ira Lupu, The Increasingly Anachronistic Case Against School Vouchers, 13 Notre Dame J.L. ETHICs \& PUB. PoL'y 375, 395 (1999). See also James G. Dwyer, School Vouchers: Inviting the Public into the Religious Square, 42 WM. \& MARY L. REV. 963, 992 (2001) (advocating requiring religious private schools to accept regulatory strings as conditions on their participation in school-voucher programs to ensure that the "money is being used to provide secular education, rather than to support denial of a good secular education and perhaps even activities that affirmatively harm children - for example, explicit and aggressive sexist training"); Martha Minow, Should Religious Groups be Exempt from Civil Rights Laws?, 48 B.C. L. REv. 781 (2007) (advocating "avoiding direct confrontation [of legal battles] between the government and religious groups" by pursuing negotiated solutions); David Saperstein, Public Accountability and Faith-Based Organizations: A Problem Best Avoided, 116 HARV. L. REV. 1353, 1393 (2003) ("The courts have not fully addressed the validity of the exemption 
participate in the programs. $^{39}$ One of the primary reasons for supporting a school voucher program is the hope of giving low-income children access to improved educational opportunities. ${ }^{40}$ Fewer schools participating in the program, ${ }^{41}$ however, would diminish the hopes of gains in student performance extolled by voucher proponents.

This Article considers the involvement by religious schools in a school voucher program and the effect this could have on the schools' employment practices. ${ }^{42}$ Part I examines current employment-discrimination law for religious

where government-funded programs or positions are involved. ... It did not ... address the issue of government-funded entities or positions. Lower court decisions doing so have been split.”).

${ }^{39}$ See Douglas Dewey, Separating School and State: A Prudential Analysis of Tax-Funded Vouchers, in Vouchers and Educational Freedom: A Debate, 269 Cato Institute Policy ANALYsis, March 12, 1997, available at http://www.cato.org/pubs/pas/pa-269.html. Mr. Dewey favors privatizing education (eliminating public schools) but fears that any movement towards school vouchers would come with strings that would strangle private schools and evaporate their success. "[G]overnment money always comes with strings attached.” Id. Several commentators have noted the analogy between federal financial-aid grants to students attending colleges and universities, including religiously affiliated institutions, and voucher programs. See Marc D. Stern, On School Vouchers and the Establishment Clause: School Vouchers - The Church-State Debate That Really Isn't, 31 ConN. L. REv. 977, 990 (1999) (noting that higher education institutions usually do not forgo government money when subsequent strings are attached). See, also, George W. Dent, Jr., Of God and Caesar: The Free Exercise Rights of Public School Students, 43 CASE W. RES. L. REV. 707, 750 (1993); Kimberly M. DeShano, Note, Educational Vouchers and the Religion Clauses under Agostini: Resurrection, Insurrection, and a New Direction, 49 CASE W. RES. L. REV. 747, 776 (1999).

40 "Power and choices make people feel more involved, more effective and more satisfied as citizens. Children whose parents can choose their best educational environment learn better and have a better chance to become productive American citizens." William Trainor, The Controversial School Voucher Issue, EconEdLInK ECONOMIcsMinute, Dec. 8, 2000, at http://www.econedlink.org/lessons/index.cfm?lesson=EM185 (quoting Milton \& Rose Friedman); Petitioner's Reply Brief at 3-4, Zelman v. Simmons-Harris, 536 U.S. 639 (2002) (No. 00-1751); see generally Petitioner’s Brief, Zelman v. Simmons-Harris, 536 U.S. 639 (2002) (No. 00-1751).

${ }^{41}$ R. Kenneth Godwin \& Frank R. Kemerer, SchoOl Choice Tradeoffs: Liberty, Equity, AND DIVERSITY $194 \& 282 \mathrm{nn} .1-2$ (2002) (citing TERRY MOE, SCHOOLS, VOUCHERS, AND THE AMERICAN Public ( 2001) and Lana Muraskin \& STEPHANIE Stullich, Final RePORT: BarRiers, Budgets, and Costs Using Private Schools to Alleviate Overcrowding in Public Schools (1998) to show that most parents support regulating private schools in voucher programs while most of those schools would refuse to participate in a voucher program if regulations were part of the deal).

${ }^{42}$ It is unclear whether jurisdictions employing school-voucher programs have attempted to condition participation in the programs on compliance with antidiscrimination employment policies. Compare OHIO REV. CODE ANN. §§ 3313.976(A)(6) (2008) (requiring that schools in the Cleveland program 
schools operating outside a voucher program. Specifically, this Part argues that the ability of religious schools to discriminate depends both on who they are discriminating against and the type of discrimination practiced. Part II asks whether allowing religious schools outside school-voucher programs exemptions from antidiscrimination laws violates the Establishment Clause. This Part argues that the dominant Establishment Clause test is inappropriate when analyzing accommodations for religious organizations, such as exemptions from employment antidiscrimination laws. In its place, I craft a new test incorporating factors from several Supreme Court cases to clarify the permissible from the impermissible accommodation. Part III considers whether a religious school's participation in a school-voucher program alters the Establishment Clause analysis for governmentcreated accommodations. Part IV addresses whether the Free Exercise, either alone or in combination with other constitutionally guaranteed rights, mandates that state and local governments provide exemptions for religious schools. Finally, Part V asks whether these same governments could rescind a religious school's exemptions as a condition of participating in a voucher program. This Part concludes that restrictions on the religious schools' ability to discriminate with respect to certain employees, but not others, would create an unconstitutional condition on participation in voucher programs. Overall, this Article demonstrates that, with some caveats, private religious schools can be included in, and cannot be excluded from, participation in a school-voucher program solely due to their hiring and firing practices.

"do[] not discriminate on the basis of race, religion, or ethnic background); WIS. STAT. ANN. § 119.23 (2006) (requiring schools to comply with the general antidiscrimination provisions of 42 U.S.C. § 2000d); UTAH CODE ANN. § 53A-1a-709 (2007) (stating that "nothing in this part grants additional authority to any state agency or school district to regulate private schools except as expressly set forth in this part”). In his Zelman v. Simmons-Harris dissent, Justice Souter suggested that the Ohio statute may prohibit a "participating religious school [from] choos[ing] a member of its own clergy to serve as teacher or principal over a layperson of a different religion claiming equal qualification for the job.” Zelman v. Simmons-Harris, 536 U.S. 639, 712-13 (Souter, J., dissenting). 


\section{PART I: EMPLOYMENT-DISCRIMINATION LAWS AND PRIVATE RELIGIOUS SCHOOLS}

This Part argues that religious organizations, such as religious schools, can currently discriminate in employment through three mechanisms. First, like other employers, they can discriminate against those outside of protected classes. I argue that even within these protected groups, religious organizations should be allowed an exemption from local antidiscrimination laws when an employee's conduct conflicts with the religious organization's moral code of conduct or tenets. Second, religious organizations can discriminate based on religious affiliation because of an exemption from federal antidiscrimination statutes. ${ }^{43}$ Lastly, religious organizations enjoy a ministerial exception that allows any type of discrimination for certain key positions. This Part considers each of these mechanisms in turn.

\section{SECTION I.A. DISCRIMINATION BASED ON CONDUCT}

Like all employers, religious organizations are permitted to discriminate based on characteristics not protected by antidiscrimination laws. For example, an environmental-advocacy group could refuse to hire people who proclaimed their desire to destroy the rainforest; similarly a conservative think tank could fire

${ }^{43}$ The federal law prohibiting employment discrimination is Title VII of the Civil Rights Act. It prohibits discrimination based on "...." The prohibitions against employment discrimination based on religion, however, "shall not apply ... to a religious corporation, association, educational institution, or society with respect to the employment of individuals of a particular religion to perform work connected with the carrying on by such corporation, association, educational institution, or society of its activities." 42 U.S.C. § 2000e-1(a) (2008). Additionally, Title VII provides that "it shall not be an unlawful employment practice for a school, college, university, or other educational institution or institution of learning to hire and employ employees of a particular religion if such school, college, university, or other educational institution or institution of learning is, in whole or in substantial part, owned, supported, controlled, or managed by a particular religion or by a particular religious corporation, association, or society, or if the curriculum of such school, college, university, or other educational institution or institution of learning is directed toward the propagation of a particular religion.” 42 U.S.C. § 2000e-2(e)(2) (2002). For the remainder of this Article, these two sections will be collectively called the "Title VII exemption." 
someone because their car sported bumper stickers supporting Barak Obama's presidential campaign. ${ }^{44}$ Similarly, a religious organization can refuse to hire or choose to fire someone whose conduct conflicts with the religion's moral code. ${ }^{45}$

One case, Little $v$. Wuerl, provides a good example of how religious organizations can discriminate based on conduct. ${ }^{46}$ Susan Long Little, a Protestant, taught elementary school at St. Mary Magdalene Parish, a Catholic school. ${ }^{47}$ Her teaching contract was not renewed because she failed to have her first marriage annulled before she remarried. ${ }^{48}$ Mrs. Little sued the school for religious discrimination. $^{49}$ The school responded that Mrs. Little's contract renewal was denied not because she was Protestant but because her conduct conflicted with Catholic tenets. ${ }^{50}$ The school claimed that they would have fired a Catholic teacher for the same behavior. ${ }^{51}$ The court agreed with the school, stating that "[i]t does not violate [antidiscrimination laws] for a parochial school to discharge a Catholic or a non-Catholic teacher who has publicly engaged in conduct regarded by the school as inconsistent with its religious principles."52

${ }^{44}$ Carl H. Esbeck, Charitable Choice and the Critics, 57 N.Y.U. AnN. SuRV. AM. L. 17, 22 (2000).

${ }^{45}$ For example, a religious teacher may be fired from a Catholic school because her support for abortion conflicts with the Church's tenets. Maguire v. Marquette University, 814 F.2d 1213, 1218 (7th Cir. 1987). See also David Saperstein, Public Accountability and Faith-Based Organizations: A Problem Best Avoided, 116 HARV. L. Rev. 1353, 1389-90 (2003); Frederick Mark Gedlicks, A TwoTrack Theory of the Establishment Clause, 43 B.C. L. REV. 1071 (2002).

${ }^{46} 929$ F.2d 944 (3rd Cir. 1991).

${ }^{47}$ Id. at 944 .

${ }^{48}$ Id. at 946.

${ }^{49}$ Id. at 945 .

${ }^{50}$ Id. at 946. "The integration of religious truth and values with the life is brought about in the Catholic school not only by its unique curriculum but, more important, by the presence of teachers who express an integrated approach to learning and living in their private and professional lives." Id. at 948 n.5 (quoting NATIONAL CONFERENCE OF CATHOLIC Bishops, TO TEACH AS JESUS Did (1972)).

${ }^{51}$ Id. at 946.

${ }^{52}$ Id. at 951. 
While it is a relatively straight-forward case when conduct-based employment decisions concern someone belonging to a group not protected by antidiscrimination laws, such as the would-be rainforest destroyer or the divorcedbut-not-annulled Mrs. Long, the issue becomes more complicated when the conduct is practiced solely by those within a group protected by federal, state, or local antidiscrimination laws. For example, homosexuality ${ }^{53}$ and non-marital sexual relations ${ }^{54}$ are inconsistent with the beliefs of several major religious organizations. The Catholic Church, which dominates the religious private-school market, ${ }^{55}$ condemns both homosexual activity and non-marital sexual relations in its tenets. These two groups, however, may be protected by antidiscrimination statutes. Could a Catholic school legally fire an employee who marched in a gay-pride parade or who was unmarried and pregnant?

\footnotetext{
${ }^{53}$ Some religions consider homosexual conduct against their church's values, while others do not. For example, in Boy Scouts v. Dale, religious organizations supporting and opposing the Boy Scouts' employment action against a homosexual Scout leader filed amici briefs. See, e.g., Brief of Amici Curiae United States Catholic Conference and New Jersey Catholic Conference at 4, Boy Scouts of America v. Dale, 530 U.S. 640 (2000) (No. 99-699) (stating that "homosexual conduct is wrong”); Brief of Amici Curiae Aguduth Israel of America at 2, Boy Scouts of America v. Dale, 530 U.S. 640 (2000) (No. 99-699) (noting that this national Orthodox Jewish organization "regard[s] ... homosexual conduct ... [as] an abomination"); Brief of Amici Curiae The General Board of Church and Society of the United Methodist Church, The United Church Board For Homeland Ministries, The Religious Action Center Of Reform Judaism, The Diocesan Council Of The Episcopal Diocese Of Newark And The Unitarian Universalist Association at 3-4, Boy Scouts of America v. Dale, 530 U.S. 640 (2000) (No. 99-699) (stating that "gay boys and men are [not] immoral [and, rather,] discrimination against gay people is immoral”).

${ }^{54}$ Religions officially opposed to premarital sex include Conservative Judaism, Orthodox Judaism, Catholicism, Greek Orthodox, Evangelical Lutheranism, Mormonism, and Southern Baptist. See Teachings on Chastity and Premarital Sex in All Faiths, available at http://www.beliefnet.com/features/chastity_chart.html. For an example of a specific prohibition, see Persona Human: Declaration on Certain Questions Concerning Sexual Ethics, Section VII, Sacred Congregation for the Doctrine of the Faith (Dec. 29, 1975), available at http://www.newadvent.org/library/docs_df75se.htm).

55 John F. Witte, The Market Approach to Education: An ANALysis of America's First VOUCHER PROGRAM 30 (1999).
} 
Section I.A.1: Conduct Concerning Groups Protected by Federal, State, or Local Antidiscrimination Laws

Section I.A.1.a: Homosexuality

While sexual orientation is not a suspect classification under federal civil rights laws, ${ }^{56}$ many states and localities have recently expanded their civil rights codes to prohibit discrimination based on sexual orientation or gender identity. ${ }^{57}$

In Hall v. Baptist Memorial Health Care Corporation, ${ }^{58}$ the Sixth Circuit addressed employment discrimination by a religious organization based on sexual orientation. Glynda Hall worked as a student-services specialist at the Baptist Memorial College of Health Sciences. ${ }^{59}$ The school was affiliated with the Southern Baptist Convention which “deplore[d] homosexuality as a perversion of divine standards and as a violation of nature and natural affections." ${ }^{60}$ Ms. Hall became a lay minister at her own non-Baptist church which actively sought homosexual

${ }^{56}$ DeSantis v. Pacific Telephone \& Telegraph Co., 608 F.2d 327, 333 (9th Cir. 1979).

57 For state and local codes prohibiting discrimination based on sexual orientation, see Josiah N. Drew, Note, Caught Between the Scylla and Charybdis: Ameliorating the Collision Course of Sexual Orientation Anti-Discrimination Rights and Religious Free Exercise Rights in the Public Workplace, 16 B.Y.U. J. PUB. L. 287, nn. 20-23 (2002). "Most civil rights legislation designed to protect against sexual orientation discrimination has taken root at the state and local levels of government. Currently, twelve states and the District of Columbia prohibit such workplace discrimination. [These statutes] [c]over[] discrimination not only in employment, but also in housing and public accommodations. . . . Additionally, eight states have executive orders that bar discrimination in public employment based upon sexual orientation. Finally, in addition to state law, over 165 municipalities and countries have enacted anti-discrimination legislation based upon sexual orientation.” Id. According to Terry Morehead Dworkin, “[t]here are over 100 ... statutes, ordinances and executive orders” prohibiting discrimination based on sexual orientation. Terry Morehead Dworkin, It's My Life - Leave Me Alone: Off The-Job Employee Associational Privacy Rights, 35 AM. Bus. L.J. 47, n. 79. See also Rhoda McMillon, Congress to Revisit Job Parity Issue, A.B.A. J., Nov. 1994, at 98. Some localities' ordinances contain explicit exemptions for religious institutions. See, e.g., Hyman v. Louisville, 132 F. Supp. 2d 528, 545 (W.D. Kent. 2001) (discussing such exemptions in Louisville and Jefferson County, Kentucky ordinances).

${ }^{58} 215$ F.3d 618 (6th Cir. 2000).

${ }^{59}$ Id. at 622.

${ }^{60} \mathrm{Id}$. 
members. ${ }^{61}$ When Ms. Hall informed her supervisor that she was a lay minister of the other church, she was asked to leave her position. ${ }^{62}$ She refused and was fired because she was a lesbian and because she publicly opposed the Southern Baptist Convention's position on homosexuality through her leadership role in her church. ${ }^{63}$ The court held that religious organizations have the right "to terminate an employee whose conduct or religious beliefs are inconsistent with those of [the] employer."64 To do otherwise would mean that the court was instructing the religious organization about "how to carry out their religious missions or how to enforce their religious practices." 65

Section I.A.1.b: Non-marital sexual activity

Religious organizations can fire men and women who violate religious tenets forbidding non-marital sexual relations. ${ }^{66}$ In Boyd v. Harding Academy of Memphis, ${ }^{67}$ a religious school affiliated with the Church of Christ fired an unmarried female teacher when she announced her pregnancy. ${ }^{68}$ The court found that Ms. Boyd was not fired because she was pregnant but because she engaged in conduct - sex outside of marriage - that the school's religious affiliate opposed. ${ }^{69}$ The school

${ }^{61} I d$.

${ }^{62}$ Id. at 623 . The College asked her to resign as a student-services specialist and offered to place her in another position that did not deal with students. Id.

${ }^{63}$ Id. at 627.

${ }^{64}$ Id. at 624.

${ }^{65}$ Id. at 626 .

${ }^{66}$ Redhead v. Conference of Seventh-Day Adventists, 440 F. Supp. 211, 223 (E.D.N.Y. 2006).

${ }^{67} 88$ F.3d 410 (6th Cir. 1996).

${ }^{68} \mathrm{Id}$. at 412.

${ }^{69} \mathrm{Id}$. at 414. 
demonstrated that on other occasions it had terminated both male and female employees for having sex outside of marriage. ${ }^{70}$ Additionally, the school had offered to maintain Ms. Boyd's employment if she married her baby's father. ${ }^{71}$

The evidence of non-marital sex often, as in Boyd, ends up being a pregnancy by an unmarried woman. If the religious school cannot demonstrate that the prohibition against non-marital sex is applied evenhandedly ${ }^{72}$ to both male and female employees and not just to pregnant women, this action could run afoul of Title VII's prohibition of discrimination based on pregnancy ${ }^{73}$ as well as state and local pregnancy-discrimination prohibitions.

Section I.A.2: Religious Schools Conduct-Based Firings and Refusals-to-Hire Based on Conduct, not Status.

Ms. Boyd was not fired by the Church of Christ because she was pregnant but rather because her pregnancy was evidence that she, an unmarried woman, had engaged in non-marital sex. The church would have fired her if it had discovered her conduct through some means other than her pregnancy. The pregnancy did not get her fired - it was the activity that got her pregnant that got her fired.

Similarly, when the Baptist Community Health Care Association fired Ms. Hall, it did so because she was actively participating in activities that directly conflicted with the church's teachings. She was not fired because she was a lesbian, but because she was promoting homosexuality. When a firing or a refusal-to-hire is based on conduct, it must be separated from a similar action based on an employee's

${ }^{70} \mathrm{Id}$. “There were no situations described at trial in which [the school] was aware of an employee's sexual activity outside of marriage and failed to take action.” Id. at 412.

${ }^{71} I d$.

${ }^{72}$ Redhead v. Conference of Seventh-Day Adventists, 440 F. Supp. 211, 223 (E.D.N.Y. 2006).

7342 U.S.C. $\S 2000 \mathrm{e}(\mathrm{k})$ (2002) prohibits "sex discrimination on the basis of pregnancy. See also Cline v. Catholic Diocese, 206 F.3d 651, 658-659 (6th Cir. 1999). 
status within the protected group. So, for example, if Ms. Hall (a lesbian) was not in a homosexual relationship nor outwardly refuting church teachings, there would have been no argument that the church fired her based on her status alone.

To deny religious organizations the ability to fire or to refuse-to-hire employees based on this conduct seriously infringes on the church's ability to convey their message. How seriously would congregants or religious followers heed church tenets and teachings if obvious and vocal evidence of an employee's disdain for those teachings was ignored? To force religious organizations to condone what their teachings proscribe as sinful would be the equivalent of government dictating the religious message.

Section I.B. Discrimination Based on Religious Affiliation: The Title ViI EXEMPTION

Title VII generally proscribes employment discrimination based on religion, sex, race or national origin, ${ }^{74}$ but provides a limited exemption for religious discrimination by religious organizations, including schools. ${ }^{75}$ This exemption applies to positions that are religious, such as clergy, and to those that are not, such as janitorial staff. ${ }^{76}$ A religious employer may require all, some, or none of its employees to be religious followers. ${ }^{77}$ For example, the Roman Catholic

\footnotetext{
${ }^{74} 42$ U.S.C. § 2000e-2 (2002).

${ }^{75}$ See supra note 43. Most state employment-discrimination statutes also allow an exemption for religious discrimination by religious organizations. See, e.g., Dayton Christian Schools v. Ohio Civil Rights Commission, 766 F.2d 932, 941 n.18 (6th Cir. 1985) (listing all the state statutes in force in 1985), reversed on abstention grounds, 477 U.S. 619 (1986).

${ }^{76}$ Corporation of the Presiding Bishop of the Church of Jesus Christ of Latter-Day Saints v. Amos, 483 U.S. 327 (1987) (upholding against Establishment Clause challenge the termination of a janitorial staff member who did not secure a certificate showing his qualifications for temple under the Mormon faith).

${ }^{77}$ Of course, some faiths may choose not to exclude those whose conduct violates church teachings in an effort to educate or reform the wayward. The issue here, however, is whether government legislation should force them to adopt this position.
} 
Archdiocese of Chicago, which runs the largest non-public school system in the nation, ${ }^{78}$ requires all new teachers to earn four "Continuing Education Units" in Catholic Doctrine within the first three years of their employment. ${ }^{79}$ In 1984, the Diocese of Pittsburgh announced a Catholics-only hiring policy and required any school hiring a non-Catholic to obtain special permission. ${ }^{80}$

The Title VII exemption, however, does not allow religious organizations to discriminate based on the statute's other proscribed bases - race, sex, or national origin. $^{81}$ For example, a religious publisher cannot adjust employees pay according to their gender and marital status without violating Title VII’s prohibition on sex

${ }^{78}$ Cathleen Falsani \& Rosalind Rossi, Saving Schools has Price, ChICAGo Sun-TimES, Jan. 26, 2001, Late Sports Final Edition, at 6.

${ }^{79}$ Policy 220.1, Evangelization And CateChesis NeWs, Archdiocese of Chicago, October 2001.

80 See Little v. Wuerl, 929 F.2d 944, 946 (3d Cir. 1991). It is not unusual for religiously-affiliated higher-education institutions to require employees to belong to a particular faith. For example, Regent's University requires all "trustees, officers, administrators, and faculty" to attest to the following statements:

1. That the Holy Bible is the inspired, infallible and authoritative source of Christian doctrine and precept.

2. That there is one God, eternally existent in three persons: Father, Son, and Holy Ghost.

3. That man was created in the image of God but, as a result of sin, is lost and powerless to save himself.

4. That the only hope for man is to believe [in] the Lord Jesus Christ, the virgin-born son of God, who died to take upon Himself the punishment for the sin of mankind, and who rose from the dead, so that by receiving Him as Savior and Lord, man is redeemed by His blood.

5. That Jesus Christ will personally return to Earth in power and glory.

6. That the Holy Spirit indwells those who receive Christ, for the purpose of enabling them to live righteous and holy lives.

7. That the Church is the body of Christ and is comprised of all those who through belief in Christ have been spiritually regenerated by the indwelling Holy Spirit. The mission of the Church is worldwide evangelization and the nurture and discipling of Christians.

Regent University, Employee Handbook, Section I Introduction, Statement of Faith, updated Feb. 18, 2005. "The board of trustees, along with the faculty and staff of the University, are committed to an evangelical interpretation and application of the Christian faith.” Id.

81 See, e.g., Cline v. Catholic Diocese, 206 F.3d 651, 658 (6th Cir. 1999); Hopkins v. Women’s Division, General Board of Global Ministries, The United Methodist Church, 238 F. Supp. 2d 174, 180-81 (D.D.C. 2002). 
March 26, 2008

discrimination. $^{82}$ Determining whether an employment decision was either permitted religious discrimination or prohibited sex, race, or national origin discrimination presents the chief factual issues courts face in this area. ${ }^{83}$

\section{SECTION I.C. THE Ministerial EXCEPTION}

Courts generally refuse to apply Title VII altogether when fired employees who serve in clearly religious positions, such as clergy, allege employmentdiscrimination claims. $^{84}$ This so-called “ministerial exception," a court-made doctrine that is based on constitutional grounds, forecloses inquiry into discrimination claims that would otherwise fall outside the Title VII exemption, such as claims of race, sex, and national origin discrimination. ${ }^{85}$

${ }^{82}$ EEOC v. Pacific Press Publishing Association, 676 F.2d 1272, 1276 (9th Cir. 1982).

${ }^{83}$ Several cases suggest that, at least in some cases, the EEOC may not even conduct a thorough investigation into why employees were terminated. For example, in EEOC v. Mississippi College, the Fifth Circuit found that the EEOC could not investigate a claim where the college said the adverse employment action was religious discrimination while the former employee claimed that it was race discrimination. 626 F.2d 477, 485 (5th Cir. 1980). "We conclude that if a religious institution of the kind described in [the Title VII exemption] presents convincing evidence that the challenged employment practice resulted from discrimination on the basis of religion, [the Title VII exemption] deprives the EEOC of jurisdiction to investigate further to determine whether the religious discrimination was a pretext for some other form of discrimination.” Id. The EEOC can, however, investigate claims based on prohibited forms of discrimination when convincing evidence is not presented by the religious organization. Ninth \& O Street Baptist Church v. EEOC, 616 F. Supp. 1231, 1233 (W.D. Ky. 1985).

${ }^{84}$ Courts have also refused to apply other employment-related federal statutes such as the Fair Labor Standards Act, Shaliehsabou v. Hebrew Home of Greater Washington, Inc., 363 F.3d 299, 305 (4th Cir. 2004); the Americans with Disabilities Act, Starkman v. Evans, 198 F.3d 173, 174 (5th Cir. 1999); the Age Discrimination in Employment Act, Tomic v. Catholic Diocese of Peoria, 442 F.3d 1036, 1041 (7th Cir. 2006); and the Family Medical Leave Act, Fassl v. Our Lady of Perpetual Help Roman Catholic Church, No. 05-CV-0404, 2005 U.S. Dist. LEXIS 22546, at *20 (E.D. Penn. Oct. 5, 2005) when faced with a ministerial plaintiff. But see Elvig v. Calvin Presbyterian Church, 375 F.3d 951, 964 (9th Cir. 2004) (holding that a sexual-harassment claim could proceed despite the plaintiff's ministerial status); Geary v. Visitation of the Blessed Virgin Mary Parish School, 7 F. 3d 324 (3d Cir. 1993) (holding that age-discrimination suit was not barred by the ministerial exception).

85 " [C]ourts have consistently found that Title VII does not apply to the relationship between ministers and the religious organizations that employ them, even where discrimination is alleged on the basis of race or sex.” Little v. Wuehl, 929 F.2d 944, 947 (3d Cir. 1991). The ministerial exception "prohibit[s] a church from being sued under Title VII by its clergy.” Gellington v. Christian Methodist Episcopal 
Courts invoking the ministerial exception state that its rationale lies in both the Free Exercise and the Establishment Clauses. ${ }^{86}$ Courts typically hold that if government may dictate that a religious organization employ certain individuals as ministers, it will inexorably hamper those organizations' ability of the organization to "select those who will carry out its mission." 87 "[T]he church as an institution must retain the ... right to select its voice.”88 On the Establishment Clause side, having the state essentially choosing whom a church may select as its leader begins to look similar to a government-sponsored church. ${ }^{89}$ Even beyond this concern, though, having the government involved in hiring decisions concerning the leaders

Church, Inc. 203 F.3d 1299, 1304 (11th Cir. 2000). “The exception precludes any inquiry whatsoever into the reasons behind a church's ministerial employment decision for the Free Exercise Clause protects the act of a decision rather than a motivation behind it.” EEOC v. Roman Catholic Diocese of Raleigh, 213 F.3d 795, 801 (4th Cir. 2000) (quoting Rayburn v. General Conference of SeventhDay Adventists, 772 F.2d 1164, 1169 (4th Cir. 1985)).

${ }^{86}$ See, e.g., Bryce v. Episcopal Church in the Diocese of Colorado, 289 F.3d 648, 655 (10th Cir. 2002); Bollard v. The California Province of the Society of Jesus, 211 F.3d 1331, 1331 (9th Cir. 2000) (Wardlaw, J., dissenting from denial of rehearing en banc); Gellington v. Christian Methodist Episcopal Church, 203 F.3d 1299, 1304 (11th Cir. 2000). See also Michael McConnell, Accommodation of Religion: An Update and a Response to the Critics, 60 GEO. WASH. L. REV. 685, 687-88 (1992) (discussing how accommodations for religious activities fall within both Religion Clauses); Samina Quddos, Accommodating Religion, 6 J. Islamic L. \& Culture 67, 69-72 (2001) (same).

${ }^{87}$ Combs v. Central Texas Annual Conference of the United Methodist Church, 173 F.3d 343, 349 (5th Cir. 1999) (quoting EEOC v. Catholic University of America, 83 F.3d 455, 462 (D.C. Cir. 1996)).

${ }^{88}$ Petruska v. Gannon Univ., 462 F.3d 294, 306 (3d Cir. 2006).

89 “Application of external social norms to religious providers' hiring decisions resembles government control over the leadership of the government-established church, particularly if the position being filled requires significant managerial or leadership responsibilities.” Frederick Mark Gedlicks, A TwoTrack Theory of the Establishment Clause, 43 B.C. L. REv. 1071 (2002). The district court explained the problem of not applying the ministerial exception as follows: "The state, through [the] court, would involve itself in theological questions and then, if finding [against the religious organization], impose upon [them] the Court's judgment as to what compromises adherence to the ... faith." Maguire v. Marquette Univ., 627 F. Supp. 1499, 1505 (E.D. Wis. 1986). 
of a faith would amount to excessive entanglement between the government and church affairs. $^{90}$

In Combs v. Central Texas Annual Conference of the United Methodist Church, ${ }^{91}$ the Fifth Circuit applied the ministerial exception to dismiss a sex discrimination claim. In that case, Reverend Pamela Combs announced her pregnancy $^{92}$ and, following the birth of her child, the church fired her. ${ }^{93}$ The church's decision did not rest on religious differences that would have excused the employment action under the Title VII exemption. ${ }^{94}$ Instead, the defendant claimed that its decision was shielded by the ministerial exception. The court agreed and found that "the First Amendment deprives a federal court of jurisdiction to hear a Title VII employment-discrimination suit brought against a church by a member of its clergy, even when the church's challenged actions are not based on religious doctrine." 95 The church had a "fundamental right . . . to be free from government interference in [its] internal management and administration.”96

Unlike the Title VII exemption, the ministerial exception is deep in application, but narrow in scope in that it only applies to certain positions. While clergy and church leaders are included, janitors and maintenance workers are not. ${ }^{97}$

\footnotetext{
${ }^{90}$ Rayburn v. General Conference of Seventh-Day Adventists, 772 F.2d 1164, 1171 (4th Cir. 1985).

${ }^{91} 173$ F.3d 343 (5th Cir. 1999).

${ }^{92}$ Reverend Combs was married so this was not a case of firing for conduct. Id. at 344. See infra Part I.A.2.

${ }^{93} I d$.

94 "Reverend Combs's claims are based purely on sex and pregnancy and do not directly involve matters of religious dogma or ecclesiastical law.” Id. at 345 n.1

${ }^{95}$ Id. at 345 .

${ }^{96} I d$. at 350 .

${ }^{97}$ Miller v. Bay View United Methodist, 141 F. Supp. 2d 1174, 1181 (E.D. Wis. 2001) (finding that the ministerial exception applies to employees whose "'primary duties consist of teaching, spreading the faith, church governance, supervision of a religious order, or supervision or participation in religious ritual and worship”” (quoting Rayburn v. General Conference of Seventh-Day Adventists,
} 
Determining to whom the exception applies depends on the functions of the position. If the job entails leading a church congregation or spreading the faith, the exception will apply. ${ }^{98}$ From the case law, it appears that teachers can be included in the ministerial exception, ${ }^{99}$ although whether their position involves spreading the faith will ultimately be a question for the court. ${ }^{100}$ In NLRB v. Catholic Bishop, a case holding that the National Labor Relations Board had no jurisdiction over lay teachers at religious schools, the Supreme Court "recognized the critical and unique role of the teacher in fulfilling the mission of a church-operated school."101 ${ }^{1 n}$ a more recent case, the Fourth Circuit held that the ministerial exception protected a religious school that fired a music teacher because music was an "integral portion of the spiritual message.”102

772 F.2d 1164, 1169 (4th Cir. 1986)); EEOC v. Roman Catholic Diocese of Raleigh, 213 F.3d 795, 797 (4th Cir. 2000); Shaliehsabou v. Hebrew Home of Greater Washington, Inc., 363 F.3d 299 (4th Cir. 2004) (finding kosher food inspector subject to the ministerial exception); Alicea-Hernandez v. The Catholic Bishop of Chicago, 320 F.3d 698, 704 (7th Cir. 2003) (finding ministerial exception applied to press secretary who was "responsible for conveying the message of an organization to the public as a whole); Musante v. Notre Dame of Easton Church, No. 3:01CV2352(MRK), 2004 U.S. Dist. LEXIS 5611, at *5-*6 (D. Conn. March 30, 2004) (finding ministerial exception applied to pastoral assistant whose duties included reading scripture, distributing communion, and training Eucharistic ministers and readers). But see Redhead v. Conference of Seventh-Day Adventists, $440 \mathrm{~F}$. Supp. 211 (E.D.N.Y. 2006) (finding teacher whose duties included teaching one hour per day of bible study was not a ministerial employee); Whitney v. Greater New York Corporation of Seventh-Day Adventists, 401 F. Supp. 1363, 1368 (S.D.N.Y. 1975) (ministerial exception did not apply to typistreceptionist).

${ }^{98}$ See infra Sections III.C and IV.A.

${ }^{99}$ EEOC v. Catholic Univ. of Am., 83 F.3d 455, 463 (D.C. Cir. 1995) (finding that the ministerial exception applies to “all employees ... whose primary functions serve [the religious organization's] spiritual and pastoral mission”).

100 See, e.g., Miller v. Bay View United Methodist, 141 F. Supp. 2d 1174, 1181 (E.D. Wis. 2001) ("The applicability of the ministerial exception is a question of law for the court.").

101 NLRB v. Catholic Bishop, 440 U.S. 490, 501 (1979). While not a ministerial-exception case, Catholic Bishop held that allowing the National Labor Relations Board to force church schools into collective bargaining negotiations could lead to "serious First Amendment questions." Id. at 504.

${ }^{102}$ EEOC v. Roman Catholic Diocese, 213 F.3d 795, 797 (4th Cir. 2000) (finding that the ministerial exception applies to all employees whose responsibilities include teaching, spreading the faith, or any other integral part of the spiritual message). 
The Supreme Court has not ruled directly on the court-made ministerial exception to antidiscrimination laws. The Free Exercise and Establishment Clauses, however, seem to require that government take a hands-off approach with respect to the internal structure of religious organizations. ${ }^{103}$ In an older case related to the internal structure of a church but not related to employment, the Supreme Court said that the First Amendment required "an independence from secular control or manipulation - in short, power [for religious organizations] to decide for themselves, free from state interference, matters of church government as well as those of faith and doctrine."104

\section{Part II: The Establishment Clause, Religious Freedom, AND ACCOMMODATIONS}

Despite several recent cases concerning the Establishment Clause, ${ }^{105}$ the full test of what violates the Clause remains unclear. Scholars continue to debate whether the Establishment Clause requires a separationist theory or a neutrality theory of enforcement. ${ }^{106}$ Should church and state be mutually exclusive realms

\footnotetext{
${ }^{103}$ See, e.g., Montrose Christian School Corp. v. Walsh, 770 A.2d 111, 126 (Md. 2001). Montgomery County, Maryland made discrimination based on religion illegal except for employees who "perform purely religious functions" for religious organizations. Id. at 114. The Maryland Court of Appeals found that the provision violated the United States Constitution (and the Maryland constitution) because it did not provide a ministerial exception as required by the Free Exercise Clause. Id. at 12228. The court reasoned that even a minister's job is not "purely" religious and, therefore, discrimination in his hiring would violate the ordinance. Id. at 128. See also Stephanie Kaye Baron, A Missed Opportunity to Take a Clear Stance on the Constitutionality of Discriminatory Employment Practices by Religious Organizations, The Maryland Survey 2000-2001,, 61 MD. L. REV. 869, 869 (2002) (discussing Montrose).

${ }^{104}$ Kedroff v. St. Nicholas Cathedral, 344 U.S. 94, 116 (1952).

105 See, e.g., Zelman v. Simmons-Harris, 536 U.S. 639 (2002); Mitchell v. Helms, 530 U.S. 793 (2000).

106 See Philip Hamburger, Separation of Church And State 335-492 (2002); Patrick M. Garry, Religious Freedom Deserves More than Neutrality: The Constitutional Argument for Nonpreferential Favoritism of Religion, 57 FLA. L. REV. 1 (2005); Frederick Mark Gedicks, A Two-Track Theory of the Establishment Clause, 43 B.C. L. REv. 1071, 1101 (2002) ("The basic insight provided by the
} 
where no governmental assistance flows to religious institutions; or should government provide benefits in a religiously-blind fashion even if that means taxpayer dollars end up in religious coffers? In cases concerning aid to religious schools, the neutrality theory appears to have declared victory. ${ }^{107}$ With respect to accommodations for religious organizations, such as exemptions from employmentdiscrimination laws, however, the neutrality theory appears ill-suited. ${ }^{108}$ Yet, the Supreme Court claims to apply the same analysis to both aid and accommodation cases: the three-pronged test first posited in Lemon $v$. Kurtzman. ${ }^{109}$

two-track theory of the Establishment Clause is that separation, not neutrality, is the more fundamental Establishment Clause value.”); Steven K. Green, Of (Un)Equal Jurisprudential Pedigree: Rectifying the Imbalance between Neutrality and Separationism, 43 B.C. L. REv. 1111 (2002); Douglas Laycock, The Religion Clauses in the 21st Century: Substantive Neutrality Revisited, 110 W. VA. L. REV. 51 (2007); Douglas Laycock, The Underlying Unity of Separationism and Neutrality, 46 EMORY L.J. 43 (1997); Ira C. Lupu, The Lingering Death of Separationism, 62 GeO. WASH. L. Rev. 230 (1994); Matthew Gaus, Note, Locke v. Davey: Discretion, Discrimination, and the New Free Exercise, 54 KAN. L. Rev. 533, 555-561 (2006); Sarah Waszmer, Note, Taking it Out of Neutral: The Application of Locke's Substantial Interest Test to the School Voucher Debate, 62 WASH. \& LEE L. REV. 1271, 1275-1281 (2005).

107 See Mitchell v. Helms, 530 U.S. 793 (2000) (educational material and equipment loans did not violate the Establishment Clause partly because the loans were available to both secular and nonsecular schools); Bowen v. Kendrick, 487 U.S. 589 (1988) (federal funds for research on premarital adolescent sexuality did not violate the Establishment Clause partly because the program did not consider religious affiliation in allocating funds); Robert A. Sedler, The Settled Nature of American Constitutional Law, 48 WAYNE L. Rev. 173, 326-43 (2002) (discussing the Establishment Clause's five subsidiary doctrines: primary effect and incidental benefit; secular deism; endorsement/symbolic union; accommodation for religious freedom, but not for religion; and non-discriminatory inclusion of religion).

${ }^{108}$ Robert A. Sedler, The Settled Nature of American Constitutional Law, 48 WAYNE L. Rev. 173, 326-43 (2002); "[T] rarely, if ever, meet in attempting to lift regulatory burdens on religious entities or individuals." Madison v. Riter, 355 F.3d 310, 320 (4th Cir. 2003). See also Board of Education of Kiryas Joel Village School v. Grumet, 512 U.S. 687 (1994) (finding a school district designed to include only members of a strict Jewish group violated the Establishment Clause because the boundary was not drawn in a neutral manner); Cutter v. Wilkinson, 544 U.S. 709, 724-25 (2005) (plurality opinion); Cutter v. Wilkinson, 544 U.S. 727 n.1 (2005) (Thomas, J., concurring).

${ }^{109}$ Lemon v. Kurtzman, 403 U.S. 602 (1971). The test has been used to allow: loans of secular textbooks to religious schools, Lemon v. Kurtzman, 403 U.S. 602 (1971), Meek v. Pittenger, 421 U.S. 349 (1975); constrained construction grants to religiously-affiliated colleges, Tilton v. Richardson, 403 U.S. 672 (1971); reimbursement of standardized testing costs to religious schools, Comm. For Public Ed. v. Regan, 444 U.S. 646 (1980); neutrally applied tax deductions for parents of school children, Mueller v. Allen, 463 U.S. 388 (1983); tuition expenses for handicapped students attending 
This Part argues that allowing private religious schools to discriminate in their employment practices does not violate the Establishment Clause of the First Amendment. The Supreme Court has previously held that the Title VII exemption is constitutional. But what about conduct-based discrimination and the so-called ministerial exception? Are these accommodations constitutional? And what test should be used to assess their validity? Section II.A. argues that the Lemon test has been unofficially modified through recent cases to include some concerns that should be relevant to any consideration of an accommodation for religious organizations. Section II.B. examines the few cases concerning accommodations and formulates a new test for evaluating accommodations under the Establishment Clause. In Section II.C, I apply this new test to conduct-based discrimination and the ministerial exception and find that neither violates the Establishment Clause.

\section{Section II.A. The Supreme CourT’s CATCH-All Establishment Clause Test}

In 1971, the United States Supreme Court articulated a three-pronged test for determining violations of the Establishment Clause in Lemon v. Kurtzman. ${ }^{110}$ Under

religious colleges, Witters v. Wash. Dept. of Serv. for the Blind, 474 U.S. 481 (1986); grants to religious schools to develop secular sex education programs, Bowen v. Kendrick, 484 U.S. 942 (1987); on-premises sign-language interpreters and public special-education teachers at religious schools, Zobrest v. Catalina Foothills Sch. Dist., 509 U.S. 1 (1993) (sign-language interpreter), Agostini v. Felton, 521 U.S. 203 (1997) (special education teachers for low-income children); government-provided instructional materials at religious schools, Mitchell v. Helms, 530 U.S. 793 (2000); and school-voucher programs that include religious schools, Zelman v. Simmons-Harris, 536 U.S. 639 (2002). The test has also been used to forbid salary supplements for religious school teachers, Lemon v. Kurtzman, 403 U.S. 602 (1971); and tuition tax credits for parents of private school children, Comm. for Public Ed. v. Nyquist, 413 U.S. 756 (1973). In Cutter v. Wilkinson, 544 U.S. 709, 718 n.6 (2005) (plurality opinion), an accommodations case, the Court cited the Lemon test but did not apply it. See also Van Orden v. Perry, 545 U.S. 677, 685-86 (2005) (plurality opinion) (noting that Lemon has been applied inconsistently).

${ }^{110}$ Lemon v. Kurtzman, 403 U.S. 602 (1971). Not all Justices, however, agree that the Lemon test provides a useful tool for analysis. Justice Scalia, for example, called the Lemon test the "ghoul in a late-night horror movie that repeatedly sits up in its grave and shuffles abroad, after being repeatedly killed and buried.” Lamb’s Chapel v. Center Moriches Union Free Sch. Dist., 508 U.S. 384 (1993). Justice Scalia, however, later joined the Zelman majority opinion which was based on a Lemon analysis. Zelman v. Simmons-Harris, 536 U.S. 639 (2002). 
that test, a statute cannot withstand an Establishment Clause challenge unless it (1) has a secular legislative purpose, (2) does not have the primary effect of advancing or inhibiting religion, and (3) does not excessively entangle government and religion. $^{111}$

The first prong of the Lemon test requires that the statute in question have a secular purpose. ${ }^{112}$ While statutes usually have little problem satisfying this prong, ${ }^{113}$ the Court has found several unconstitutional when no plausible secular purpose was put forth. In Stone v. Graham, for example, the Court had little trouble finding an Establishment Clause violation when reviewing a Kentucky statute that required that each public-school classroom display the Ten Commandments. ${ }^{114}$ The statute's purpose was "plainly religious in nature"115 and "no legislative recitation of a supposed secular purpose [could] blind [the Court] to that fact." ${ }^{116}$ Likewise, in Wallace v. Jaffree, ${ }^{117}$ a case involving an Alabama statute authorizing moments of silence "for meditation," "voluntary prayer," and teacher-led prayer with "willing

\footnotetext{
${ }^{111}$ Lemon v. Kurtzman, 403 U.S. 602, 612-13 (1971).

${ }^{112}$ Lemon v. Kurtzman, 403 U.S. 602, 612 (1971).

${ }^{113}$ See, e.g., Wolman v. Walter, 433 U.S. 229, 236 (1977) (finding a program that provided books for nonpublic pupils easily met Lemon's first prong, but ultimately failed to meet the other Establishment Clause requirements); Committee for Public Education v. Nyquist, 413 U.S. 756, 773 (1973) (same for a program that provided tax breaks for parents sending their children to private schools); Mueller v. Allen, 436 U.S. 388, 395 (1983) ("Little time need be spent on the question of whether the Minnesota tax deduction has a secular purpose. Under our prior decisions, governmental assistance programs have consistently survived this inquiry even when they have run afoul of other aspects of the Lemon framework. This reflects, at least in part, our reluctance to attribute unconstitutional motives to the States, particularly when a plausible secular purpose for the State's program may be discerned from the face of the statute.”) (citations omitted).

${ }^{114}$ Stone v. Graham, 499 U.S. 39, 41-42 (1980).

${ }^{115}$ Id. at 41 .

${ }^{116} I d$.

${ }^{117}$ Wallace v. Jaffree, 472 U.S. 38 (1985).
} 
students," therefore, the statute lacked the requisite secular intent. ${ }^{119}$

Impermissible effect, the second Lemon prong, has been historically the most difficult for a statute to satisfy. ${ }^{120}$ Any effect that advances or inhibits religion causes a statute to fail this prong. For example, the Court struck down several New York statutes that provided “maintenance and repair” grants to religious schools and tax credits for tuition costs of private-school students because the programs advanced religion. ${ }^{121}$ The Court found that the "maintenance and repair” grants were not sufficiently tailored to ensure that none of the grant money was ever used for buildings providing religious instruction. ${ }^{122}$ Likewise, the Court invalidated the tax credits because they encouraged parents to send their children to religious schools, thus benefiting religion. ${ }^{123}$

The last prong of the traditional Lemon test requires that the statute not create an excessive entanglement between the religious organization and the government ${ }^{124}$ for fear of "interfere[nce] with the independence of [religious] institutions." Lemon itself invalidated a state program that provided salary supplements for private

\footnotetext{
${ }^{118}$ Id. at 40 .

${ }^{119}$ Id. at 56.
}

120 "As usual in Establishment Clause cases, the more difficult question is whether the primary effect of the challenged statute is impermissible.” Bowen v. Kendrick, 487 U.S. 589, 604 (1988) (internal citations omitted).

${ }^{121}$ Committee for Public Education v. Nyquist, 413 U.S. 756, 779-80 (1973).

122 Committee for Public Education v. Nyquist, 413 U.S. 756, 775-77 (1973). Similarly, in Tilton v. Richardson, 403 U.S. 672, 683 (1971), a twenty-year prohibition on use of government funded buildings for religious instruction was insufficient to ensure that there was no advancement of religion. The Court held that the prohibition had to be for the life of the building. Id.

${ }^{123}$ Conversely, the Court has upheld programs that allow tax deductions for all parents, including those that send their children to religious schools under the neutrality theory. Mueller v. Allen, 463 U.S. 388, 397 (1983).

\footnotetext{
${ }^{124}$ Lemon v. Kurtzman, 403 U.S. 602, 613 (1971)

${ }^{125}$ Lynch v. Donnelly, 465 U.S. 668, 688 (1984) (O’Connor, J., concurring).
} 
school teachers based on this prong. ${ }^{126}$ The "careful governmental controls and surveillance by state authorities in order to ensure that state aid support[ed] only secular education” amounted to excessive entanglement because the government would have to monitor the teachers and decide what education was secular and what was not. In other words, to ensure Lemon's second prong was not violated, the government would have to be excessively entangled, thus violating its third prong. ${ }^{127}$

Early cases that employed the Lemon test followed a separationist logic and suggested that any involvement between government and religion was likely to violate the Establishment Clause. Even if a program's purpose was purely secular, the diversion of government resources to religion, ${ }^{128}$ the religious dollars the government program freed up to be used for religious purposes, ${ }^{129}$ the entanglement necessary between government and religion to ensure that government funds were not being used for religious purposes, ${ }^{130}$ and the divisiveness caused by perceived government favoritism among religions ${ }^{131}$ or towards the religious versus the

\footnotetext{
${ }^{126}$ Id. at $613-14$.

${ }^{127}$ Id. at 619 .

${ }^{128}$ Committee for Public Education v. Nyquist, 413 U.S. 756, 774 (1973); Wolman v. Walter, 433 U.S. 229, 250 (1977) (concerning non-book instruction materials and equipment), overruled in Mitchell v. Helms, 530 U.S. 793 (2000).

129 Aguilar v. Felton, 473 U.S. 402, 417-18 (1985) (Powell, J., concurring) overruled in Agostini v. Felton, 521 U.S. 203, 209 (1997).

${ }^{130}$ Lemon v. Kurtzman, 403 U.S. 602, 616 (1971); Wolman v. Walter, 433 U.S. 229, 254 (1977) (holding that government monitoring of religious school's government-funded field trip selections would lead to excessive entanglement).

131 County of Allegheny v. American Civil Liberties Union, 492 U.S. 573, 593 (1989) (quoting Wallace v. Jaffee, 472 U.S. 38, 70 (1985) (O’Connor, J., concurring in judgment)).
} 
areligious ${ }^{132}$ meant virtually any involvement between government and religion was unconstitutional. $^{133}$

In Agostini v. Felton, ${ }^{134}$ the Court modified its Establishment Clause test in two ways. First, the Court explicitly collapsed Lemon's third prong - excessive entanglement - into the test's second prong - impermissible effect. ${ }^{135}$ Second, the Court implicitly changed how it analyzed what constitutes an "impermissible effect." In addition to entanglement, two factors began to appear central to the Court's analysis of the second prong: neutrality ${ }^{136}$ and endorsement. ${ }^{137}$ Finding that it was the private decisions of individual parents that directed Title I aid to religious schools, the Court held that the program had no impermissible effect ${ }^{138}$ because the state was not indoctrinating children with religion. ${ }^{139}$ And because it was administered neutrally, the program involved no government endorsement of religion. $^{140}$

${ }^{132}$ Id.; Lee v. Weisman, 505 U.S. 577, 588-89 (1992).

${ }^{133}$ Tilton v. Richardson, 403 U.S. 672 (1971), appears to be the exception that proves the rule. The Court found that the government program providing construction grants to religious colleges was constitutional only if there were permanent limits on the use of the buildings precluding any and all religious use. Id. at 682-83. Because the case concerned buildings, Lemon's entanglement prong was satisfied because the Court believed that monitoring a building's activities in Tilton was less intrusive than watching a teacher's classroom discussion, as would have been necessary under the program at issue in Lemon. Id. at 687-88.

134521 U.S. 203 (1997) (considering a New York City program which placed public-school teachers in religious schools to provide remedial education to disadvantaged students).

${ }^{135}$ Id. at 232-33.

136 See Agostini v. Felton, 521 U.S. 203, 231 (1997); Zobrest v. Catalina Foothills Sch. Dist., 509 U.S. 1, 10 (1993); Witters v. Washington Dep’t of Services for the Blind, 474 U.S. 481, 488 (1986).

137 See Zelman v. Simmons-Harris, 536 U.S. 639, 654-55 (2002); County of Allegheny v. American Civil Liberties Union, 492 U.S. 573, 593 (1989); Lynch v. Donnelly, 465 U.S. 668, 690 (1984) (O’Connor, J., concurring).

${ }^{138}$ Agostini v. Felton, 521 U.S. 203, 225 (1997).

${ }^{139}$ Id. (citing Witters v. Washington Dep’t of Services for the Blind, 474 U.S. 481, 487 (1986)).

${ }^{140}$ Id. at 234-35. 
The Court uses the twin pillars of neutrality and endorsement to illuminate the "impermissible effect" prong. While neutrality has always played an important role in Establishment Clause jurisprudence, ${ }^{141}$ it has recently taken on new importance. In Mitchell v. Helms, ${ }^{142}$ Justice O’Connor, in her concurrence, criticized the plurality for giving the neutrality "factor singular importance" because she believed it should be just one of several factors considered. ${ }^{143}$ In fact, Justice O’Connor joined the Zelman v. Simmons-Harris ${ }^{144}$ majority that approved a school voucher program partly because the program was applied neutrally. ${ }^{145}$ All schools religious or secular - could participate in the program. ${ }^{146}$

Even if a program is neutral, however, targeted government funding could be equivalent to an endorsement of religion and, thus, create the prohibited impermissible effect. ${ }^{147}$ In Mitchell v. Helms, Justice O’Connor concentrated on the program's combination of neutrality and non-endorsement. ${ }^{148}$ According to Justice

${ }^{141}$ Id. at 231.

142 Mitchell v. Helms, 530 U.S. 793 (2000). The program provided school classroom equipment, such as audio-visual equipment, globes, laboratory equipment, and maps, to schools where a certain portion of the student body was poor. The program included religious schools. Id. at 802.

${ }^{143}$ Id. at 837 (O’Connor, J., concurring). Justice Souter, in his dissent, also criticized the plurality for the weight they placed on the program’s neutrality. Id. at 900 (Souter, J., dissenting).

${ }^{144}$ Zelman v. Simmons-Harris, 536 U.S. 639 (2002).

${ }^{145} I d$.

${ }^{146} I d$. at 653 .

${ }^{147}$ Mitchell v. Helms, 530 U.S. 793, 838 (2000) (O’Connor, J., concurring). Justice O’Connor first suggested the “endorsement test” in Lynch v. Donnelly, 465 U.S. 668, 690-91, 692 (1984) (O’Connor, J., concurring) (finding a crèche included in a holiday display along with secular symbols on public property did not violate the Establishment Clause because the government did not endorse the crèche's religious message). While Justice O’Connor continued to apply the endorsement test, she found an Establishment Clause violation only once, in County of Allegheny v. American Civil Liberties Union, 492 U.S. 573, 634 (1983) (O’Connor, J., concurring) (finding a stand-alone crèche suggested government endorsement and was unconstitutional).

${ }^{148}$ Id. at 838-842 (O’Connor, J., concurring). Specifically, Justice O’Connor focused on perceived endorsement through significant diversion of government resources. 
O’Connor, no reasonable observer would believe the government was endorsing religious education by providing maps, globes, and audio-visual equipment. ${ }^{149}$

The endorsement theory depends on either the government's purpose in enacting the statute ${ }^{150}$ or the actual effect of the statute. ${ }^{151}$ Statutes fail this Establishment Clause test when the government speaker intends to promote religion or religious practice or when a reasonable observer would perceive the statute as an endorsement of religion or religious practice. ${ }^{152}$ Government endorsement - either actual or perceived - violates the Establishment Clause because it "sends a message to nonadherents that they are outsiders, not full members of the political community, and an accompanying message to adherents that they are insiders, favored members of the political community.”,153

\section{Section II.B. A New Test for Assessing Religious AcCommodations}

"The government may (and sometimes must) accommodate religious practices.”154 But analyzing accommodations for religion or religious exercise based

\footnotetext{
${ }^{149}$ In previous cases, the Court had found the opposite. Id. at 804, 808 (overruling Meek v. Pittenger, 421 U.S. 349 (1971) and Wolman v. Walter, 433 U.S. 229 (1977)). These earlier cases held that government provision of school equipment would allow religious schools to devote more resources to religious teaching and, thus, government would be assisting the religious mission of the schools. Id. at 804. Based on this rationale, outsiders could reasonably believe that government was providing the equipment in order to make it easier for religious schools to indoctrinate children.

${ }^{150}$ Lynch v. Donnelly, 465 U.S. 668, 690 (1984) (O’Connor, J., concurring) ("The purpose prong of the Lemon test asks whether government's actual purpose is to endorse or disapprove religion.”).

151 Id. at 690-91 (O’Connor, J., concurring) ("The effect prong asks whether, irrespective of government's actual purpose, the practice under review in fact conveys a message of endorsement of disapproval.”).

${ }^{152} I d$.

${ }^{153}$ Lynch v. Donnelly, 465 U.S. 668, 688 (1984) (O’Connor, J., concurring).

${ }^{154}$ Hobbie v. Unemployment Appeals Comm’n, 480 U.S. 136, 144 (1987). But not all Justices agree. Justice Stevens, in his concurrence in City of Boerne v. Flores, 521 U.S. 507, 536-37 (1997), suggests that any government measure that shows a "preference for religion, as opposed to irreligion” violates the Establishment Clause. Thus, no accommodation would pass muster.
} 
on the tripartite Lemon criteria creates a paradox. ${ }^{155}$ After all, the very purpose of all religious accommodations is to assist religion and their effect may very well benefit religious organizations relative to secular ones. ${ }^{156}$ It is hard to imagine any accommodation that would not violate a pure application of Lemon. On the other hand, if accommodations are merely removing government-imposed burdens that unequally harmed religious entities relative to secular ones or violated the Free Exercise Clause, the accommodation's purpose looks more “secular” and its effect less like assisting religion than removing government limitations on religious practice. $^{157}$ Without guidance from the Court and due to these difficulties, courts have continued to contort Lemon when considering accommodations for religion or religious exercise under the Establishment Clause. ${ }^{158}$ This Section formulates a new

155 One court called the test for accommodations a refined Lemon test. Ehlers-Renzi v. Connelly Sch. of the Holy Child, 224 F.3d 283, 288 (4th Cir. 2000). See also Ira C. Lupu, The Trouble with Accommodations, 60 GEO. WASH. L. REV. 743 (1992); Ira C. Lupu, Reconstructing the Establishment Clause: The Case Against Discretionary Accommodation of Religion, 140 U. PA. L. REV. 555 (1991); Michael W. McConnell, Accommodation of Religion: An Update and a Response to the Critics, 60 GEO. WASH. L. REV. 685, 700-02 (1992) (distinguishing accommodations that remove a significant obstacle to the exercise of religious belief from those that induce a person to adopt a religion in order to benefit from the accommodation).

156 David Saperstein, Public Accountability and Faith-Based Organizations: A Problem Best Avoided, 116 HARV. L. REV. 1353, 1370 (2003).

157 “There exists an overriding interest in keeping the government - whether it be the legislature or the courts - out of the business of evaluating the relative merits of differing religious claims. The risk that governmental approval of some or disapproval of others will be perceived as favoring one religion over another is an important risk the Establishment Clause was designed to preclude." United States v. Lee, 455 U.S. 252, 263 n.2 (1982) (Stevens, J., concurring in judgment). "[I]t is a permissible legislative purpose to alleviate significant governmental interference with the ability of religious organizations to define and carry out their religious missions.” Corporation of the Presiding Bishop of the Church of Jesus Christ of Latter-Day Saints v. Amos, 483 U.S. 327, 335 (1987).

158 “At some point accommodation may devolve into an unlawful fostering of religion. . . ." Corporation of the Presiding Bishop of the Church of Jesus Christ of Latter-Day Saints v. Amos, 483 U.S. 327, 334-35 (1987) (quoting Hobbie v. Unemployment Appeals Comm'n, 480 U.S. 136, 145 (1987). Amos, perhaps the most well-known accommodations case, has been called "one of the most deferential and least logically convincing Establishment Clause analyses ever undertaken by the Court." Scott C. Idleman, The Religious Freedom Restoration Act: Pushing the Limits of Legislative Power, 73 TeXAs L. REv. 247, 290-91 (1994). "The line between benevolent neutrality and permissible accommodation, on the one hand, and improper sponsorship or interference, on the other, must be 
test for accommodations by incorporating neutrality and endorsement to clarify the line between permissible and impermissible accommodations. ${ }^{159}$

\section{Section II.B.1: The Courts and Accommodations}

In Corporation of the Presiding Bishop of the Church of Jesus Christ of Latter-Day Saints v. Amos, the Supreme Court considered the constitutionality of the Title VII exemption against an Establishment Clause challenge. ${ }^{160}$ Specifically, the Court considered whether the religious employer could discharge an employee who could not show that he was a member of the Church even though the employee's job was not of a religious nature. ${ }^{161}$ In a unanimous decision, the Court found that the Title VII exemption met the requirements of the three-pronged Lemon test. ${ }^{162}$ The Court reasoned that the Title VII exemption served a secular legislative purpose because it "alleviate[d] significant governmental interference with the ability of religious organizations to define and carry out their missions.”" ${ }^{63}$ The Court added

delicately drawn both to protect the free exercise of religion and to prohibit its establishment.” EhlersRenzi v. Connelly Sch. of the Holy Child, 224 F.3d 283, 287-88 (4th Cir. 2000). See also Carl H. Esbeck, A Constitutional Case for Government Cooperation with Faith-Based Social Service Providers, 46 EMORY L.J. 1, 18 (1997); Michael W. McConnell, Accommodation of Religion: An Update and a Response to the Critics, 60 GeO. WASH. L. REV. 685 (1992) (arguing that accommodation is required because of the Free Exercise Clause while neutrality is required by the Establishment Clause). Professor Ira Lupu says this "might be seen as double-dipping by religious institutions, which rely on their sectarian character in their quest for autonomy in selecting employees while simultaneously seeking a place as a religion-neutral dispenser of government benefits.” Ira C. Lupu, Government Messages and Government Money: Santa Fe, Mitchell v. Helms, and the Arc of the Establishment Clause, 42 WM. \& MARY L. REV. 771, 820 (2001).

${ }^{159}$ Some accommodations may be mandated by the Free Exercise Clause. See infra Part IV. Section II.B only concerns what accommodations satisfy the Establishment Clause.

160483 U.S. 327 (1987) (using a Lemon test analysis to determine whether the exemption violated the Establishment Clause).

${ }^{161} I d$. at 331. Amos concerned a janitor who failed to secure a temple recommend which is a sign of adherence to the tenets of Mormonism. Id. at 330-32.

${ }^{162}$ Id. at 335.

${ }^{163} I d$. 
that " $[\mathrm{w}]$ here ... government acts with the proper purpose of lifting a regulation that burdens the exercise of religion, [there is] no reason to require that the exemption come packaged with benefits to secular entities."164 Further, the Court held that the exemption did not advance or inhibit religion ${ }^{165}$ nor did it amount to an excessive entanglement between church and state. ${ }^{166}$

Just two years later, the Supreme Court considered another accommodation for religion in Texas Monthly v. Bullock. ${ }^{167}$ At issue was a Texas statute that provided a tax exemption for religious, but not secular, periodicals. ${ }^{168}$ In upholding the program against an Establishment Clause challenge, the Texas Court of Appeals said the state designed the exemption to limit the state's involvement with religion. ${ }^{169}$ The Supreme Court reversed, holding that the program unconstitutionally singled out religious periodicals for a benefit not available to other, non-religious periodicals that were also providing benefits to the

${ }^{164}$ Id. at 338.

${ }^{165} I d$. at 337. The Court stated that "a law is not unconstitutional simply because it allows churches to advance religion, which is their very purpose." Id. The "Government itself" did not use its influence to advance religion. Id.

${ }^{166}$ Id. at 339. The Court noted that the intention of the exemption was to alleviate much of the entanglement that would be caused by government involvement in religious organization's hiring decisions. Id. at 336. They left open whether applying the exemption to for-profit religious entities violated the Establishment Clause. Id. at 339; id. at 340 (Brennan, J., concurring). This could raise interesting questions regarding for-profit religious schools participating in school-voucher programs, although the author is not aware of any such schools participating in existing programs. As such, the topic of this Article is limited to non-profit religious organizations.

167 Texas Monthly v. Bullock, 489 U.S. 1 (1989).

${ }^{168} I d$. at 5-6.

${ }^{169}$ Id. at 6-7. The Texas Court of Appeals had applied the Lemon test. Specifically, the exemption (1) served to preserve the separation between church and state, (2) had the effect of "permit[ting] religious organizations to be independent of government support or sanction," and (3) did not entangle government and religious organizations because the state's tax authorities based qualification for the exemption on the publisher's status as a religious organization and did not require a level of religiousness in the publications. Id. 
community. ${ }^{170}$ Unlike the accommodation in Amos, there was no evidence that requiring religious periodicals to pay sales taxes would hinder religious activity and "[n]o concrete need to accommodate religious activity [had] been shown." ${ }^{171}$ The Court noted that only accommodations that do not "impose substantial burdens on nonbeneficiaries"172 or "that were designed to alleviate government intrusions that might significantly deter adherents of a particular faith from conduct protected by the Free Exercise Clause”173 could pass constitutional muster. An example of such a permissible accommodation would be one designed to avoid excessive entanglement between church and state. ${ }^{174}$

More recently, ${ }^{175}$ the Court considered an Establishment Clause challenge to the Religious Land Use and Institutionalized Persons Act (RLUIPA) in Cutter v. Wilkinson. ${ }^{176}$ In upholding the provisions of the Act concerning prison inmate's religious expression rights, the Court mentioned but did not apply the Lemon test. ${ }^{177}$ Instead, the Court found that the challenged provisions of RLUIPA “alleviate[d] exceptional government-created burdens on private religious exercise,"178 required

\footnotetext{
${ }^{170} I d$. at 14 .

${ }^{171}$ Id. at 18 .

${ }^{172} I d$.

${ }^{173} I d$.
}

${ }^{174} I d$. "[Amos] prevented potentially serious encroachments on protected religious freedoms. Texas' tax exemption, by contrast, does not remove a demonstrated and possibly grave imposition on religious activity sheltered by the Free Exercise Clause.” Id.

175 The Court found a narrow religious accommodation unconstitutional in Board of Education of Kiryas Joel Village School District v. Grumet, 512 U.S. 687 (1994). In that case, New York provided a special school district for one religious group. Id. at 690. See infra notes 195-196 and accompanying text for more discussion of this case.

${ }^{176} 544$ U.S. 709 (2005).

${ }^{177}$ Cutter v. Wilkinson, 544 U.S. 709, 718 n.6 (2005).

${ }^{178}$ Cutter v. Wilkinson, 544 U.S. 709, 720 (2005). 
“courts [to] take adequate account of the burdens a requested accommodation may impose on nonbeneficiaries," administered neutrally among different faiths." ${ }^{180}$ The Court, however, neither explained why it did not apply the Lemon test nor whether its current analysis is meant to either replace or bolster a traditional Lemon analysis. ${ }^{181}$

\section{Section II.B.2: A New Test for Accommodations}

It is obvious that some accommodations are constitutionally required, such as those mandated by the Free Exercise Clause ${ }^{182}$ while other accommodations are prohibited because they would violate the Establishment Clause. ${ }^{183}$ The bulk of accommodations may lie between the two clauses - not forbidden by the Establishment Clause but not required by the Free Exercise Clause. At issue here is how we test which of these accommodations are permissible and which are not. The uncomfortable fit when applying Lemon to accommodations and the tensions between Amos, Texas Monthly, and Cutter demonstrate the need for a clearer Establishment Clause test for accommodations.

It is clear that any new accommodations test must be rooted in the principle that government should not act to favor religion over non-religion. ${ }^{184}$ The government, however, must acknowledge and appreciate the differences between

\footnotetext{
${ }^{179}$ Cutter v. Wilkinson, 544 U.S. 709, 720 (2005).

${ }^{180}$ Cutter v. Wilkinson, 544 U.S. 709, 720 (2005).

${ }^{181}$ Justice Thomas, in his concurrence in Cutter v. Wilkinson, is clear: Lemon should not be used and is “discredited.” Cutter v. Wilkinson, 544 U.S. 709, 727 n.1 (2005) (Thomas, J., concurring).

${ }^{182}$ For example, it may be required by the Free Exercise Clause that Catholic churches be granted exemptions from drinking-age laws to allow younger members to fully participate in communion.

${ }^{183}$ It would clearly violate the Establishment Clause if Catholic churches but not other faiths were exempted from drinking-age laws.

${ }^{184}$ Board of Education of Kiryas Joel Village School District v. Grumet, 512 U.S. 687, 696 (1994).
} 
religion and non-religion in order to not disfavor one over the other. ${ }^{185}$ Properly tailored accommodations provide one mechanism for government to neither favor nor disfavor religion. An accommodation satisfies this requirement when it concerns an activity central to religious practice, treats religions neutrally, cannot reasonably be viewed as a government endorsement of religion or the religious practice, and its absence would excessively entangle government and religion. The Court should adopt this four-part test for Establishment Clause analysis of accommodations and finally bury the ill-fitting Lemon test.

The first element of the new test - allowing religion to be religious - replaces Lemon's first prong which looked at whether a statute's purpose was secular. By definition, accommodations for religious organizations cannot have a purely secular purpose. $^{186}$ After all, accommodations act by exempting religious organizations from laws that non-religious entities must continue to follow. Application of Lemon's first prong would invalidate any and all accommodations for religious organizations, as long as the reviewing court holds true to Lemon's plain language. It is hard to conceive of how a law exempting a group would not be perceived as providing a benefit to that group and thus its purpose was to benefit them.

Changing the "secular purpose" prong of Lemon to instead inquire whether the purpose of an accommodation was to allow religious organizations to be religious does not mean that any and all accommodations will suddenly become permissible. At some point, government accommodations of religion or religious practice will become the equivalent of promoting religion, in general, or a religion, in particular. The line, therefore, is that accommodations from general laws for

185 "Separtionism, at its most basic level, presumes that government should, at times, must, treat religion distinctively.” Steven K. Green, Of (Un)Equal Jurisprudential Pedigree: Rectifying the Imbalance between Neutrality and Separationism, 43 B.C. L. REV. 1111, 1126 (2002).

186 The Court in Amos found that the Title VII exemption did have a secular purpose - keeping government out of religious organization's affairs. But that same argument could be made for not applying any laws to religious organizations. This, of course, would go too far. The Establishment Clause test for accommodations proposed here aims to draw the line between permissible and impermissible accommodations. 
religious groups must be based on the need to not prejudice religious practice. ${ }^{187}$ For example, by allowing a church to decide who spreads their message, the government accommodation permits the religion to do what it is designed to do - be religious. On the other hand, giving a religious magazine a tax credit that is not available to other magazines merely gives the religious publisher a financial advantage not enjoyed by his secular competitors. Where the "impact [of neutral laws] on religious belief is minimal," ${ }^{188}$ accommodation looks more like favoritism towards religion than "free[ing religious organizations] from state interference.”"189

With respect to the conduct-based and ministerial exemptions from employment-discrimination laws, a religion's tenets may require an employee to be a member in good standing, ${ }^{190}$ follow church standards for daily life, ${ }^{191}$ or change personal characteristics, traits, or behaviors to conform to religious doctrine. ${ }^{192} \mathrm{~A}$ religion's official position on morality does not have to be popular or generally accepted within the community for First Amendment protections to apply. ${ }^{193}$ While

${ }^{187}$ Government should provide "a spirit of freedom for religious organizations, an independence from secular control or manipulation - in short, power to decide for themselves, free from state interference, matters of church government as well as those of faith and doctrine.” Kedroff v. Saint Nicholas Cathedral of the Russian Orthodox Church in North America, 344 U.S. 94, 116 (1952).

${ }^{188}$ EEOC v. Pacific Press Publishing Association, 676 F.2d 1272, 1279 (9th Cir. 1982).

${ }^{189}$ Kedroff v. Saint Nicholas Cathedral of the Russian Orthodox Church in North America, 344 U.S. 94, 116 (1952).

${ }^{190}$ Good standing may be defined as attending church regularly.

191 Amos dealt with a janitor in a Mormon facility that had not earned his "temple recommend." Corporation of the Presiding Bishop of the Church of Jesus Christ of the Latter-Day Saints v. Amos, 483 U.S. 327, 330 (1987). This certification from the Mormon Church requires adherence to "the Church's standards in such matters as regular church attendance, tithing, and abstinence from coffee, tea, alcohol, and tobacco.” Id. at 330 n.4.

192 This may include requiring individuals to conceal their sexual preference or not engage in nonmarital sex.

193 See Thomas v. Review Bd. of Indiana Employment Security Div., 450 U.S. 707, 714 (1981) ("Religious beliefs need not be acceptable, logical, consistent, or comprehensible to others to merit First Amendment protection"). "It is not within the judicial ken to question the centrality of particular 
other members of the community may not agree with the religious organization's moral code and may even abhor what they perceive as intolerance, the fact remains that it is for the church to decide what employees will best convey the religion's message. To allow the community, through government regulation, to control a church's message is the equivalent of the government dictating what that message is. While commentators can and do disagree about the proper meaning of the Establishment Clause, all would agree that a national church is, at minimum, prohibited by the Clause.

Second, accommodations must be neutral among religions to ensure that government is not favoring one religion over another. ${ }^{194}$ In Board of Education of Kiryas Joel Village School District v. Grumet, the Supreme Court found that drawing a school district to exclusively include one particular religious enclave was unconstitutional. $^{195}$ One of the Court's chief concerns was that it would be impossible for the Court to ensure that other religious groups would get the same kind of accommodation. ${ }^{196}$ In a similar vein, government cannot condition a religious accommodation on adherence to any particular religion. For example, this element of the new accommodations test would be violated if only adherents of some, but not all, faiths could qualify for the accommodation.

Some commentators contend that releasing religious organizations from governmental burdens imposed on non-religious groups violates the Establishment

beliefs or practices to a faith, or the validity of particular litigants' interpretations of those creeds.” Employment Division v. Smith, 494 U.S. 872, 887 (1990).

194 “[E]venhanded neutrality can be viewed as advancing equality values by removing barriers to religious participation in generally available programs. Neutrality theory provides that individuals and organizations should not be disabled from participating in government benefits programs simply because of their religious character and states its goal as minimizing government influences on private religious choices.” Steven K. Green, Of (Un)Equal Jurisprudential Pedigree: Rectifying the Imbalance between Neutrality and Separationism, 43 B.C. L. REV. 1111, 1132 (2002).

195512 U.S. 687, 690 (1994).

${ }^{196}$ Id. at 702-03. 
Clause because it non-neutrally provides a benefit to religion. ${ }^{197}$ Allowing religious schools to discriminate in employment while not allowing non-religious schools the same latitude may appear non-neutral at first. But this argument ignores the fact that government must allow religion to be religious or it runs the risk of appearing to disfavor religion relative to non-religion. By not providing accommodations for religious activities, government would be discriminating against religion. ${ }^{198}$ The latitude to choose the leaders of their faith and to employ only those who share the religion's beliefs and conduct their lives based on the religion's tenets gives religious organizations the same control that non-religious organizations have. Government can remove burdens for religious groups, so long as that same burden is removed for all religions and is not designed to benefit one religion over another. ${ }^{199}$

Establishment Clause jurisprudence has long been concerned with whether government action acts as an improper imprimatur for religious activity. The third element of the new test - no perceived endorsement - echoes this tradition. Accommodations meeting the first two prongs of the new accommodations test, however, will generally not be viewed as government endorsements. ${ }^{200}$

197 Ira C. Lupu, Reconstructing the Establishment Clause: The Case Against Discretionary Accommodation of Religion, 140 U. PA. L. REV. 555 (1991).

${ }^{198}$ Carl H. Esbeck believes that the neutrality rule means "that the government cannot intentionally discriminate against religion.” Carl H. Esbeck, The Establishment Clause as a Structural Restraint on Governmental Power, 84 IowA L. REv. 1 (1998).

${ }^{199} I d$.

200 "A generally available exemption program, with a potentially unlimited number of participants, is unlikely to be perceived as favoring religion or to create religious dissension or competition. On the contrary, [a tax] exception will likely lead to greater autonomy and independence of religious entities, thus ensuring greater separation of the two spheres.” Steven K. Green, Of (Un)Equal Jurisprudential Pedigree: Rectifying the Imbalance between Neutrality and Separationism, 43 B.C. L. REV. 1111, 1134 (2002). 
While accommodations only provide benefits to religious organizations, ${ }^{201}$ "government itself" is not promoting or advancing religion by providing an exemption. ${ }^{202}$ Rather, the accommodation merely removes an impediment to private religious activity. ${ }^{203}$ In effect, by providing the accommodation, government is only “endors[ing] ... free exercise of religion and not ... a particular religion or even ... religion in general.”204 For example, Justice O’Connor's Amos concurrence found that although the Title VII exemption had a non-secular purpose, it met the strictures of the Establishment Clause because the "objective observer [would] perceive the Government action [the Title VII exemption] as an accommodation of the exercise of religion rather than as a Government endorsement of religion.”205

Allowing religious organizations to discriminate in employment based on conduct or by invoking the ministerial exception ${ }^{206}$ cannot be viewed by an objective observer as a government endorsement of religion because such accommodations are merely removing government-imposed burdens so that organizations may spread their message. For conduct, all private employers, not just religious ones, may discriminate on the basis of an employee's viewpoint. By exempting religious organizations from local anti-discrimination laws, government would be providing religious schools with "permission" to discriminate while not condoning that

${ }^{201}$ Corporation of the Presiding Bishop of the Church of Jesus Christ of Latter-Day Saints v. Amos, 483 U.S. 327, 333 (1987). The lower court found that the exemption granted religious organizations "an exclusive authorization to engage in conduct which can directly and immediately advance religious tenets and practices.” Id. (quoting lower court's opinion).

${ }^{202}$ Id. at 337 (italics in original). "A law is not unconstitutional simply because it allows churches to advance religion, which is their very purpose.” Id.

${ }^{203} I d$.

204 Johnson v. Martin, 223 F. Supp. 2d 820, 824 (W.D. Mich. 2002).

${ }^{205}$ Corporation of the Presiding Bishop of the Church of Jesus Christ of Latter-Day Saints v. Amos, 483 U.S. 327, 348-49 (1987) (O’Connor, J., concurring).

${ }^{206}$ See supra Part I for discussion of employment discrimination based on conduct, the Title VII exemption for religious discrimination, and the ministerial exception for certain positions. 
discrimination. The legislature would merely be acknowledging that religion holds a special place in our constitutional framework and that certain narrowly-tailored accommodations act by ensuring that religious institutions can continue to spread the message unhindered by government regulations. The school, not the state, discriminates against potential and current employees. In the case of religion teachers or teachers of subjects basked in religion, ${ }^{207}$ that discrimination is rooted in the concern that only religious adherents can properly convey the church's message. Without the ministerial exception, government would be too heavily involved in internal church affairs giving rise to the fear that government would be speaking for religion itself. Such accommodations can no more be perceived as a government endorsement of religious practice than having the government issue a parade permit to a neo-Nazi group could be seen as a government endorsement of their racist politics.

Lastly, any accommodation must avoid entanglement between government and religion. In most cases, avoiding such entanglement may be the accommodation's very purpose. For example, in Amos, the Court found that the Title VII exemption's purpose was to avoid entanglement between religious organizations and employment-related government agencies. ${ }^{208}$ Not all entanglement, however, rises to the level of “excessive entanglement” identified in the Lemon test. While an accommodation that relieves excessive entanglement may be constitutionally required by the Establishment Clause, one that merely alleviates government from monitoring a religious organization's activities may be permissible, but not mandated under the Clause. That is, an accommodation that is

\footnotetext{
207 'Numerous courts have held that the term 'religious institution,' in [the context of the ministerial exception] can include religiously affiliated schools, hospitals, and corporations." Shaliehsabou v. Hebrew Home of Greater Washington, Inc., 363 F.3d 299, 309 (4th Cir. 2004) (citations omitted).

${ }^{208}$ Corporation of the Presiding Bishop of the Church of Latter Day Saints v. Amos, 483 U.S. 327, 336 (1987).
} 
not designed to reduce entanglement looks more like favoritism towards religion than government relieving burdens. ${ }^{209}$

The secular purpose stated in Amos was to keep government from interfering in the religious decision making inherent in hiring and firing decisions. ${ }^{210}$ Exemptions from antidiscrimination laws for religious schools alleviate the need for government officials and courts to determine what qualifies as an “important” job qualification for the religious school's employees. For example, a Catholic school wanting to hire only devout Catholic teachers for religion classes could, without the ministerial exemption or the Title VII provision, be forced to hire an atheist. If the school refused to hire the otherwise qualified teacher, the applicant could claim discrimination and file suit against the church. ${ }^{211}$ The school would be forced to justify its hiring decision in court and a judge would have to determine if belief in God was a bona fide occupational qualification for the position. This process would necessarily involve government inspection of all the papers, meetings, and decisions of the hiring personnel. Additionally, the court would have to decide just how religious religion teachers must be. ${ }^{212}$ These types of decisions are better left to the religious organizations themselves because government involvement with religion carries too much risk of either having religion co-opt government to do its bidding or

209 See, e.g., Texas Monthly v. Bullock, 489 U.S. 1 (1989).

${ }^{210}$ Corporation of the Presiding Bishop of the Church of Latter Day Saints v. Amos, 483 U.S. 327, 335-36 (1987). “This does not mean that the law’s purpose must be unrelated to religion - that would amount to a requirement 'that the government show a callous indifference to religious groups'. . . Lemon's 'purpose' requirement aims at preventing the relevant governmental decisionmaker . . . from abandoning neutrality and acting with the intent of promoting a particular point of view in religious matters.” Id. at 335.

${ }^{211}$ See id. at 336. The Court pointed out that the "[f]ear of potential liability might affect the way [a religious] organization carried out what it understood to be its religious mission” without the Title VII exemption applying to both secular and religious employees. Id.

212 " [I]t is a significant burden on a religious organization to require it, on pain of substantial liability, to predict which of its activities a secular court will consider religious.” Id. 
government dictating religion. ${ }^{213}$ To preserve both the secular and the religious realm, government must remain outside religious decisionmaking. ${ }^{214}$

${ }^{213}$ John Locke, A Letter Concerning Toleration (1689), in Two TREATISES ON GOVERNMENT AND A LETTER CONCERning TOLERATION 215, 247-51(Ian Shapiro ed., 2003). Government should avoid investigating employment-discrimination claims where it would require government interpretation of religious canons or when the inquiry would intrude on internal church governance, both of which could be inherently coercive. See Tomic v. Catholic Diocese of Peoria, 442 F.3d 1036 (7th Cir. 2006).

${ }^{214}$ Corporation of the Presiding Bishop of the Church of Latter Day Saints v. Amos, 483 U.S. 327, 339 (1987). "[T] he statute effectuates a more complete separation of [church and state] and avoids the kind of intrusive inquiry" that would be required absent the exemption. Id. 
March 26, 2008

\section{Part III: Does Government Money Change The Outcome?}

Where they exist, voucher programs have been popular among participants ${ }^{215}$ and have shown success in improving test scores and educational opportunities. ${ }^{216}$ Approximately 55,000 students ${ }^{217}$ participate in voucher programs in Arizona, ${ }^{218}$ Florida, ${ }^{219}$ Georgia, ${ }^{220}$ Ohio, Utah, ${ }^{221}$ Wisconsin, ${ }^{222}$ and the District of Columbia. ${ }^{223}$ And it is likely that participation numbers will only increase as state budgets for vouchers rise and information about the programs spread. ${ }^{224}$ Most of the students in

${ }^{215}$ Washington Scholarship Fund, Latest Report form Georgetown University Shows Strong Support for D.C. Scholarship Program, Dec. 20, 2007, available at http://www.washingtonscholarshipfund.org/news/news/pr_12_20_07.html. The Georgetown study found that parents had an "increased focus on and pride in their children's academic development. The scholarship families - who are all low-income and have become informed and savvy 'consumers' of educational options - report that their children are thriving academically and socially in the schools of their choice."

${ }^{216}$ Jay P. Greene, Education Myths : What Special Interest Groups Want You to Believe AвOUT OuR SCHOOLS, AND WHY IT ISN'T So 151 (2005).

${ }^{217}$ Dan Lips, School Choice: Policy Developments and National Participation Estimates in 20072008, Heritage Foundation Backgrounds No. 2102 (Jan. 31, 2008), available at http://www.heritage.org/Research/Education/upload/bg_2102.pdf .

${ }^{218}$ Limited to special needs students and children in foster care.

${ }^{219}$ Limited to special needs students.

${ }^{220}$ Limited to special needs students.

${ }^{221}$ Limited to disabled students.

${ }^{222}$ Limited to economically disadvantaged children in Milwaukee.

${ }^{223}$ Limited to economically disadvantaged children.

${ }^{224}$ Milwaukee's program began in 1990 with just 337 students but has expanded to over 17,500 participating students in 2007. Dan Lips, School Choice: Policy Developments and National Participation Estimates in 2007-2008, Heritage Foundation Backgrounds No. 2102 (Jan. 31, 2008), available at http://www.heritage.org/Research/Education/upload/bg_2102.pdf (citing Wisconsin Department of Public Instruction, Milwaukee Parental Choice Program: Facts and Figures for 20072008 (Nov. 2007), available at http://dpi.state.wi.us/sms/doc/mpc07fnf.doc; School Choice Wisconsin, Milwaukee Parental Choice Program (Nov. 2005), available at http://www.schoolchoiceinfo.org/facts/index.dfm?fl_id=1. In D.C., the program was so popular that four students applied for every voucher available. Washington Scholarship Fund, Latest Report form 
the programs attend religious schools, ${ }^{225}$ which is not surprising given that most of the schools participating are parochial.

While exemptions from employment antidiscrimination laws for religious schools do not violate the Establishment Clause, what if the school participates in a publicly funded voucher program? How does government involvement change the analysis? Are employment accommodations for religious schools participating in the program $^{226}$ still permissible, or do they penetrate the "wall of separation between church and state"? ${ }^{227}$ To answer this question, we must apply the accommodations methodology developed in Part II.

The first element of the new accommodations test asks whether the purpose of the accommodation is to allow religious organizations to act in a manner consistent with their religious dictates. In other words, does permitting religious voucher schools to discriminate based on conduct, religion, or for ministerial

Georgetown University Shows Strong Support for D.C. Scholarship Program, Dec. 20, 2007, available at http://www.washingtonscholarshipfund.org/news/news/pr_12_20_07.html.

${ }^{225}$ For example, for the 2001-2002 school year, 76.2\% of students in the Milwaukee Parental Choice Program attended private religious schools and 70 of the 104 schools participating in the program were religious institutions. Howard L. Fuller \& Deborah Greiveldinger, The Impact of School Choice on Racial Integration in Milwaukee Private Schools, American Education Reform Council 6 (August 2002), available at http://www.schoolchoiceinfo.org/data/research/integ0802.pdf. In Florida, 62\% of the schools participating in the John M. McKay Scholarship Program for Students with Disabilities Program are religious schools. Florida Department of Education Office of Independent Education and Parental Choice, John M. McKay Scholarships for Students with Disabilities Program, available at http://www.floridaschoolchoice.org/information/McKay/files/Fast_Facts_McKay.pdf.

${ }^{226}$ Participating in a voucher program would not transform a school into a state actor for purposes of Fourteenth Amendment analysis. See Rendell-Baker v. Kohn, 457 U.S. 830, 839-43 (1982) (finding that a private school that received $99 \%$ of its funding from the state was not a state actor for purposes of a civil-rights claim by the school's employees where the state exhibited no "encouragement" for the school's practices of suppressing speech by its employees); Blum v. Yaretsky, 457 U.S. 991, 1011-12 (1982); Lown v. Salvation Army, 393 F. Supp. 2d 223, 242-43 (S.D.N.Y. 2005). See also Brent Shelley, The Impact of School Vouchers on Employment Law: State Regulatory Interference with Private Religious Schools, 18 Regent U. L. REV. 129, 149-50 (2005/2006). The issue remains whether government-funded vouchers would invalidate any government-provided accommodations, see infra Part III, and whether government could condition participation in government -funded voucher programs on relinquishment of government-provided accommodations, see infra Part V.

${ }^{227}$ Letter from Thomas Jefferson, President of the United States, to Nehemiah Dodge, et al., Danbury Baptist Association in the State of Connecticut (Jan. 1, 1802). 
positions allow religions to be religious? Furthermore, would the failure to allow these types of discrimination create a major or a minor impediment to religious activity? Government disallowance of these types of discrimination, especially based on conduct or with respect to ministerial positions, would impose significant burdens on religious activity. State control over who speaks for a church interferes at a fundamental level with the religious message. In the context of a religious school, this is especially true for teachers of religiously-based subjects.

The next element asks whether the accommodation is applied neutrally among religions. Every voucher program now in existence is open to schools of all religious persuasions and any religion can take advantage of the employment-law exemptions. $^{228}$ Of course, the exemption would be used most fervently by those religions that condemn out-of-wedlock intercourse and homosexuality, and who are generally less tolerant of practices and views that differ from their own. ${ }^{229}$ It is important to note, however, that that outcome results from the various religions' views rather than any government favoritism.

The third element of the new accommodations test asks whether exempting religious schools participating in voucher programs from antidiscrimination laws helps to avoid excessive entanglement between church and state. While a religious school's participation in a voucher program may mean increased state involvement in the school's educational decisions, ${ }^{230}$ this involvement does not extend to

\footnotetext{
${ }^{228}$ See supra notes 6-12. Some of the programs, such as those in Ohio, prohibit schools from teaching intolerance or hate.

${ }^{229}$ It is not surprising that groups with minority views about culture and morality are the very ones who choose to open private parochial schools in the first place. Their minority views, contrasted with more the more generically Protestant or areligious public schools, may have been the impetus for creating their own schools.

${ }^{230}$ See, e.g., Committee for Public Education and Religious Liberty v. Regan, 444 U.S. 646, 648-49 (1980) (upholding against an Establishment Clause challenge a New York statute that authorized reimbursement for private schools' costs of administering standardized tests mandated by the state); see Brent Shelley, The Impact of School Vouchers on Employment Law: State Regulatory Interference with Private Religious Schools, 18 REgENT U. L. REV. 129 (2005/2006).
} 
employment decisions. For example, as a condition of participation, the state or locality may require that schools meet certain educational requirements to remain in the voucher program. ${ }^{231}$ This, however, does not keep religion from being religious, as such requirements would not hinder the religious mission of the schools. The government's involvement is limited to ensuring that the schools are meeting the criteria to participate in the program. ${ }^{232}$ Conversely, state monitoring and involvement in employment decisions ${ }^{233}$ would necessarily require the state to assess whether adherence to the religion or its tenets was a bona fide occupational qualification for a position. $^{234}$ Such an inquiry would include government determinations about how much weight various church dictates deserve and how important adherence to church doctrine is to each position. More entanglement between church and state is difficult to imagine.

The most important and relevant issue, though, for whether government funding combined with antidiscrimination law exemptions for religious schools violates the Establishment Clause is the new accommodations test's fourth and final element: could the combination reasonably be viewed as a government endorsement

${ }^{231}$ The government has to ensure that schools in the voucher program perform better than the failing public schools that generated the need for the voucher program in the first place.

${ }^{232}$ See supra notes 6-12. Utah's statute specifically states that the government's regulatory authority is limited to what is necessary to ensure that the school is meeting eligibility criteria.

${ }^{233}$ See, e.g., Little v. Wuerl, 929 F.2d 944, 948 (3d Cir. 1991). “Application of Title VII’s prohibition against religious discrimination to the Parish's decision would also be suspect because it arguably would create excessive government entanglement with religion in violation of the establishment clause." Id.

${ }^{234}$ Without this exemption, religious organizations would be forced to attempt to redefine the Title VII exemption to permit discrimination against those who may be a member of the organization's faith but who do not conduct themselves in a manner consistent with religious tenets. Cf. Pedreira v. Kentucky Baptist Homes for Children, Inc., 186 F. Supp. 2d 757, 762 (W.D. Ky. 2001) (finding that conduct-based discrimination not prohibited by statute could not be characterized as prohibited religious discrimination). The Establishment Clause test for accommodations developed in Part II is more narrowly focused than such a broad interpretation of Title VII. The accommodations test only includes those characteristics that would be central to the religious practice and would not allow a general exemption from all antidiscrimination laws to any church that could redefine what being a member of its own religion was. 
of either religion or discrimination committed by religious schools? The remainder of this Part considers this question with respect to conduct-based discrimination, religious discrimination, and the ministerial exception and ends with a discussion of possible limitations generated by participation in a government-funded program.

\section{SECTION III.A: EMPLOYMENT DISCRIMINATION AND ENDORSEMENT}

While there is considerable debate about the original meaning of the Establishment Clause, ${ }^{235}$ most commentators agree that government cannot officially create or endorse any particular religion or religion in general. Even when governmental action does not intentionally endorse, though, the Establishment Clause would be violated if a reasonable observer perceived such an endorsement. The reasoning behind this rule lies in whether adherents to non-favored faiths or atheists would feel ostracized from government favor. "Endorsement sends a message to nonadherents that they are outsiders, not full members of the political community, and an accompanying message to adherents that they are insiders, favored members of the political community."236 For religious schools in voucher programs, whether exemptions for conduct-based discrimination, the ministerial exception, and religious affiliation discrimination equate to government endorsement as viewed by the reasonable observer is key.

But reasonableness is a malleable standard. Courts must consider all the facts that the reasonable observer would view. Even though school voucher programs act through the independent, private decisions of parents, a reasonable person could, at the margins, see taxpayer dollars going to religious schools that discriminate as inching towards endorsement. To maintain a constitutional balance, accommodations must be crafted to be tighter and more narrowly tailored so as to

\footnotetext{
${ }^{235}$ See supra note 106 and notes 147-153 and accompanying text.

${ }^{236}$ Lynch v. Donnelly, 465 U.S. 668, 688 (1984) (O’Connor, J., concurring).
} 
protect against the appearance of endorsement. Where that balance lies differs among conduct-based discrimination, discrimination based on religious affiliation, and employment decisions concerning ministerial employees.

\section{III.A.1: Conduct-Based Discrimination}

As mentioned earlier, discrimination based on unmarried sexual intercourse and homosexuality ${ }^{237}$ may run afoul of federal, state, or local antidiscrimination laws. Federal law prohibits pregnancy discrimination, ${ }^{238}$ and of the locales currently with school-voucher programs, Wisconsin, ${ }^{239}$ the District of Columbia, ${ }^{240}$ and several localities in Arizona, ${ }^{241}$ Florida, ${ }^{242}$ Georgia, ${ }^{243}$ Ohio, ${ }^{244}$ and $\mathrm{Utah}^{245}$ prohibit

\footnotetext{
${ }^{237}$ See supra Section I.A.

23842 U.S.C. $\$ 2000 \mathrm{e}(\mathrm{k})(2008)$.

${ }^{239}$ WIS. STAT. §§ 111.31 - 111.36 (2006).

${ }^{240}$ D.C. Code ANN. § 2-1402.11 (2007).
}

${ }^{241}$ Local statutes in Phoenix and Tucson prohibit employment discrimination based on sexual orientation. Human Rights Campaign, WorkNet Employer Database, at http://www.hrc.org/issues/workplace/search_employers.htm (last visited Feb. 26, 2008).

${ }^{242}$ Local statutes in Broward County, Miami-Dade County, Monroe County, Palm Beach County, and the cities of Gainesville, Key West, Miami Beach, Orlando, Sarasota, St. Petersburg, Tampa, and West Palm Beach prohibit employment discrimination based on sexual orientation. Human Rights Campaign, WorkNet Employer Database, at http://www.hrc.org/issues/workplace/search_employers.htm (last visited Feb. 26, 2008).

${ }^{243}$ Local statutes in DeKalb County and the cities of Atlanta and Decatur prohibit employment discrimination based on sexual orientation. Human Rights Campaign, WorkNet Employer Database, at http://www.hrc.org/issues/workplace/search_employers.htm (last visited Feb. 26, 2008).

${ }^{244}$ Local statutes in Athens, Cincinnati, Cleveland, Columbus, Toledo, and Yellow Springs prohibit employment discrimination based on sexual orientation. Human Rights Campaign, WorkNet Employer Database, at http://www.hrc.org/issues/workplace/search_employers.htm (last visited Feb. 26, 2008).

${ }^{245}$ Local statutes in Salt Lake City prohibit employment discrimination based on sexual orientation. Human Rights Campaign, WorkNet Employer Database, at http://www.hrc.org/issues/workplace/search_employers.htm (last visited Feb. 26, 2008). 
discrimination based on sexual orientation. These statutes may conflict directly with a religious school's employment practices. ${ }^{246}$ Can allowing an exemption for conduct-based discrimination by religious schools in voucher programs reasonably be viewed as government endorsement of religion or religious practice?

The government is not promoting religion by exempting religious schools from federal, state, and local antidiscrimination laws, it is merely "getting out of the way" for the religious school to do what it was designed to do - teach children under the tenets of the religion. ${ }^{247}$ While some amount of taxpayer money could end up at a religious school that discriminates, parents - not the government - make that happen. $^{248}$ Additionally, government is not dictating church actions or determining church tenets. The church school, not the government, determines what church tenets warrant discrimination against individuals whose conduct contradicts church tenets. The combination of government absence from religious decision-making and the individual choices of parents to apply vouchers towards religious school tuition shield conduct-based exemptions from the appearance of governmental endorsement.

\section{III.A.2: The Title VII Exemption for Religious Affiliation Discrimination}

Title VII permits discrimination by religious organizations based on religious affiliation, as we have seen earlier. ${ }^{249}$ In Amos, ${ }^{250}$ the Supreme Court held that this

\footnotetext{
${ }^{246}$ Institutions that are not explicitly religious may be affected by these statutes, as well. Freedom of association grounds, however, may allow non-religious organizations whose code of conduct opposes homosexuality to discriminate in employment. Boy Scouts of America v. Dale, 530 U.S. 640, 648 (2000). Individuals, however, are not exempt. See Hyman v. Louisville, 132 F. Supp. 2d 528, 544 (W.D. Kent. 2001).

${ }^{247}$ In contrast, applying Title VII to a religious publishing house did not violate the Free Exercise Clause because "the impact on religious belief was minimal and the interest in equal employment opportunity was high.” EEOC v. Pacific Press Publishing Association, 676 F.2d 1272, 1279 (9th Cir. 1982).

${ }^{248}$ Zelman v. Simmons-Harris, 536 U.S. 639, 652 (2002).

${ }^{249}$ See supra Part I.B.
} 
exemption for religious affiliation does not violate the Establishment Clause. That opinion, however, did not apply the accommodations analysis or address the impact of government-derived funding. Instead, it used a contorted Lemon test. Would a religious school's participation in a voucher program change the result?

The addition of taxpayer funding to the Title VII exemption means that the accommodation must be more narrowly tailored to protect against any perceived government endorsement. The Title VII exemption for religious affiliation is a rule acting as a proxy for religious adherence. But, like other rules, the exemption is both over- and under-inclusive. ${ }^{251}$ For example, the exemption would shield a Catholic church that fired a non-Catholic employee who had conducted his daily life as a "good” Catholic would. In contrast, the church could not legally fire a Catholic employee who actively eschews the Church's teachings, at least not based solely on the Title VII exemption. When the exemption stood on its own, ${ }^{252}$ these problems were of less concern because a reasonable observer would view the exemption as government getting out of the way for religious organizations to be religious. Government funding of religious-school tuition clouds that message. As a result, courts may rule that Title VII exemption's sweep is too broad to survive an Establishment Clause challenge.

\section{Section III.A.3: The Ministerial Exception}

Unlike the Title VII exemption, it is highly unlikely that any court would ever hold that the ministerial exception, regardless of the presence of government money, amounted to a governmental endorsement of religion. The ministerial exception is the fundamental building block for a church independent from the

${ }^{250} 483$ U.S. 327 (1987).

251 See, e.g., EEOC v. Waffle House, Inc., 534 U.S. 279, 294 (2002); Adarand Constructors, Inc., v. Pena, 965 F. Supp. 1556, 1580 (D. Colo. 1997).

252 See Part II.B.2. 
state $^{253}$ and is evidence of the government's hands-off approach. The exception guarantees that government will remain uninvolved in the key employment decisions of religious schools. Government is neither hiring the teachers nor dictating the religious lesson plan.

Indeed, government control over a religious school's key hires or the creation of its lesson plan would be the very example of an Establishment Clause violation. More than mere entanglement would be involved - essentially government would control church speech. Without the ministerial exception, one can imagine a scenario where the government would need to determine the qualifications of religion teachers. This would put the government in the position of determining - or at least overseeing - which teachers best conveyed the religious message and, thus, altering that message. ${ }^{254}$ If anything, the removal of the ministerial exception would make it more likely that the reasonable observer would perceive government endorsement of religion than if the exception remains in place.

\section{SECTION III.B: LIMITATIONS ON ANTIDISCRIMINATION EXEMPTIONS}

While it does not appear that permitting exemptions for religious schools participating in government-funded voucher programs suggests an endorsement of religion, direct state funding of teacher salaries may. In Dodge v. Salvation Army, ${ }^{255}$ a religious employer tried to fire a Wiccan employee because of her religion. ${ }^{256}$ The

${ }^{253}$ See Part IV.

${ }^{254}$ See, e.g., Miller v. Bay View United Methodist, 141 F. Supp. 2d 1174 (E.D. Wis. 2001). The "state may no more require a minimum basis in doctrinal reasoning than it may supervise doctrinal content.” Rosati v. Toledo, Ohio Catholic Diocese, 233 F. Supp. 2d 917, 922 (2002) (quoting Rayburn v. General Conference of Seventh-Day Adventists, 772 F.2d 1164, 1169 (4th Cir. 1985)).

255 Dodge v. Salvation Army, No. S88-0353(R), 1989 U.S. Dist. LEXIS 4797 (S.D. Miss. Jan. 10, 1989).

${ }^{256}$ Dodge, 1989 U.S. Dist. LEXIS 4797, at *5. 
position was paid for directly with government funds. ${ }^{257}$ The court found that even though the religious organization was entitled to the Title VII exemption, they could not discriminate against this particular employee. ${ }^{258}$ The religious employer, however, could continue to discriminate based on religion with respect to other employees. $^{259}$

There are several problems with the Dodge opinion. First, other courts have held that religious organizations cannot waive their Title VII exemption. ${ }^{260}$ Second, Dodge applied a stricter, more separationist version of the Lemon test than the Supreme Court currently adheres to. ${ }^{261}$ For all its flaws, this Article assumes Dodge is still good law.

The key difference between the facts in Dodge and those contemplated by this Article lies in the independent decision-making of parents. In all existing school-voucher programs, government does not directly pay for teacher salaries. Instead, government funds are either sent directly to students or applied to tuition bills on their behalf. Government makes no decision about what school receives the funds or how that school uses them. Any government money that ends up in a religious school's coffers arrives there only through the independent decisions of individuals. $^{262}$ The fact that parents, not the government, decide which school the voucher goes to dramatically lessens the chances that a reasonable observer would view the combination of the Title VII exemption and participation in a voucher program as a government endorsement of religion.

\footnotetext{
${ }^{257}$ Dodge, 1989 U.S. Dist. LEXIS 4797, at *9.

${ }^{258}$ Dodge, 1989 U.S. Dist. LEXIS 4797, at *13.

${ }^{259}$ Dodge, 1989 U.S. Dist. LEXIS 4797, at *13.

260 See Saeemodarae v. Mercy Health Services-Iowa Corp., 456 F. Supp. 2d 1021, 1039 (D. Iowa 2006); Hall v. Baptist Memorial Health Care Corporation, 215 F.3d 618, 625 (6th Cir. 2000).

${ }^{261}$ See Zelman v. Simmons-Harris, 536 U.S. 639 (2002); Mitchell v. Helms, 530 U.S. 793 (2000).

${ }^{262}$ See, e.g., Zelman v. Simmons-Harris, 536 U.S. 639, 646 (2002).
} 


\section{Part IV: The Free Exercise Clause, Employment ANTIDISCRIMINATION LAWS, AND RELIGIOUS SCHOOLS IN SCHOOL Voucher Programs}

What the Establishment Clause permits, the Free Exercise Clause does not necessarily mandate. As the Court recently stated, there is "play in the joints" between the two Clauses. ${ }^{263}$ State and local governments have some latitude to regulate the secular activities of religious organizations, including private religious schools. ${ }^{264}$ But the Free Exercise Clause prohibits regulations that would infringe too much on religious activities. ${ }^{265}$

The proper mix of government accommodation of religion and the application of generally applicable laws has confounded the Court in Free Exercise cases. Early cases required accommodation for religious practice if government regulation created a substantial burden and the regulation did not pass strict scrutiny. ${ }^{266}$ Later, though, this inquiry changed to deny court-made exemptions from generally applicable laws, regardless of the burden that those laws imposed on religious practice. $^{267}$ In so doing, the Court recognized that while our Constitution provides a special place for religious exercise that is not afforded to other personal

263 See e.g., Locke v. Davey, 540 U.S. 712, 718 (2004); Cutter v. Wilkinson, 544 U.S. 709, 719 (2005).

${ }^{264}$ See, e.g., Pierce v. Society of Sisters, 268 U.S. 510, 534 (1925).

265 See, e.g., Wisconsin v. Yoder, 406 U.S. 205, 218 (1972). See also Employment Division v. Smith, 494 U.S. 872, 877 (1990) ("The government may not compel affirmation of religious belief, punish the expression of religious doctrine it believes to be false, impose special disabilities on the basis of religious views or religious status, or lend its power to one or the other side in controversies over religious authority or dogma.” (citations omitted)).

266 See, e.g., Sherbert v. Verner, 374 U.S. 398, 403-04 (1963); Wisconsin v. Yoder, 406 U.S. 205 (1972); Hobbie v. Unemployment Appeals Commission, 480 U.S. 136, 141 (1987).

${ }^{267}$ Employment Division v. Smith, 494 U.S. 872, 878 (1990). One commentator referred to this move as "gutting the Free Exercise Clause as a guarantor of religious liberty." Nadine Strossen, Religion and the Constitution: A Libertarian Perspective, 2005-06 CATO SuP. CT. REV. 7, 27 (2005/2006). 
preferences, the government has an interest in applying general laws even when they may adversely affect religion. ${ }^{268}$ Free Exercise cases, therefore, concern where the line between permissible accommodation and government favoritism lies. ${ }^{269}$

This Part asks whether the Free Exercise Clause prohibits state and local governments from regulating the relationship between religious schools and their employees. $^{270}$ Section IV.A argues that there are two types of Free Exercise cases involving generally applicable laws: those concerning internal church affairs and those that do not. This Section concludes that because the ministerial exception affects internal church affairs, any restriction prohibiting religious organizations from using it would violate the Free Exercise Clause. Section IV.B. addresses whether religious schools have a constitutional right to discriminate based on conduct. Lastly, Section IV.B. considers whether the Title VII exemption is mandated by the Free Exercise Clause.

Section IV.A: Two Types of Free Exercise Cases AND the Ministerial EXCEPTION

\footnotetext{
268 See, e.g., Robert A. Sedler, The Settled Nature of American Constitutional Law, 48 WAYNE L. REV. 173 (2002). "[A] Free Exercise Clause challenge is more difficult to sustain in that it requires a showing of governmental coercion. ...” Id. at 343.

269 “Typically, a Free Exercise Clause challenge is asserted against a facially neutral law on the ground that (1) the law compels people to do something that their religion forbids, or prohibits people from doing something that their religion requires, or (2) compliance with the requirements of the law imposes a burden on a person because of that person's adherence to religious beliefs, or (3) the law interferes with the operations of a religious organization.” Id. at 344.

270 "The limits of ... accommodation by government are not 'coextensive with the noninterference mandated by the Free Exercise Clause.” Ehlers-Renzi v. Connelly Sch. of the Holy Child, 224 F.3d 283, 287 (4th Cir. 2000) (quoting Corporation of the Presiding Bishop of Jesus Christ of Latter-Day Saints v. Amos, 483 U.S. 327, 334 (1987)).
} 
In most of its modern history, the dominant case in the Supreme Court's Free Exercise jurisprudence was Sherbert v. Verner. ${ }^{271}$ In that case, South Carolina denied unemployment benefits to a Seventh-Day Adventist who refused to accept work that included Saturday shifts. ${ }^{272}$ The state courts had sided with the state employment commission. In overturning the denial of benefits, the Supreme Court held that infringements on Free Exercise must survive strict scrutiny, i.e., the government must prove both a compelling state interest and that its regulation is narrowly tailored. ${ }^{273}$

Sherbert reigned until 1990 when the Supreme Court fundamentally altered Free Exercise jurisprudence in Employment Division v. Smith. ${ }^{274}$ As in Sherbert, the plaintiffs were denied unemployment benefits due to their religious practices. They had been fired from their jobs for disobeying a law criminalizing peyote use. ${ }^{275}$ The Oregon Supreme Court reversed that decision and held that the denial of benefits violated the plaintiffs' Free Exercise rights. In reversing, the Supreme Court

271374 U.S. 398 (1963).

${ }^{272}$ Saturday is the Sabbath for Seventh-Day Adventists. Id. at 399.

${ }^{273}$ Id. at $406-08$.

274494 U.S. 872 (1990). Following Smith, Congress passed the Religious Freedom Restoration Act (RFRA) in an effort to restore the pre-Smith Sherbert strict-scrutiny test for statutes and regulations that substantially burdened religious practice. The Court struck the portions of RFRA that applied to state laws in City of Boerne v. Flores, 521 U.S. 507, 514 (1997). Congress then passed the Religious Land Use and Institutionalized Persons Act (RLUIPA) based on its Commerce Clause and Spending Clause powers. The reach of the RLUIPA has not been fully litigated, although the Court has held that the sections concerning prison inmates do not violate the Establishment Clause. Cutter v. Wilkinson, 544 U.S. 709 (2005). If RLUIPA , RFRA (which would apply to the District of Columbia), and state-RFRAs have re-established a Sherbert-like standard of review, religious schools have a fairly strong case for arguing that exemptions from antidiscrimination laws are mandated since the laws would have to pass a strict-scrutiny analysis. See Eugene Volokh, Looking Backward, Looking Forward: The Legacy of Chief Justice Rehnquist and Justice O'Connor, Freedom of Expressive Association and Government Subsidies, 58 StAN. L. Rev. 1919, 1954-65 (2006). If, however, RLUIPA, RFRA, and state-RFRAs are not available, the case must be made under the less beneficial standard of Smith. The remainder of this Article assumes the worst from the perspective of religious schools: Smith reigns.

${ }^{275}$ Peyote is used in Native American religious practices. 494 U.S. 872, 874 (1990). 
reverted to its pre-Sherbert by saying test that "generally applicable, religion-neutral laws that have the effect of burdening a particular religious practice need not be justified by a compelling governmental interest.”276

In the wake of Smith, generally applicable laws will usually survive Free Exercise challenges. ${ }^{277}$ States enact these laws, within their police power, to curtail certain activities, but the laws are not designed to target a particular religious practice. ${ }^{278}$ A statute, however, does not violate the Free Exercise Clause when it is generally applicable ${ }^{279}$ and otherwise valid, does not have burdening religion as its object, $^{280}$ only has an incidental effect on religious practices, ${ }^{281}$ and does not implicate other constitutional rights. ${ }^{282}$

Following Smith, it was unclear whether the ministerial exception survived. Lower courts have filled the void by unanimously holding that Smith does not apply

${ }^{276}$ See id. at 886 n.3.

${ }^{277}$ Id. at 879 . "The right of free exercise does not relieve an individual of the obligation to comply with a valid and neutral law of general applicability on the ground that the law proscribes (or prescribes) conduct that his religion prescribes (or proscribes)." Id. In Church of Lukumi Babalu Aye v. City of Hialeah, 508 U.S. 520 (1993), the Court held that in addition to being generally applicable, a valid statute must also be facially neutral. In other words, the government action cannot target religious activity.

278 Smith suggests that a law designed to punish religious organizations would violate the Free Exercise Clause. Id. at 882. While noting that the Court has not directly considered such a case, the Smith majority stated "that a State would be 'prohibiting the free exercise of religion' if it sought to ban [religious] acts or abstentions only when they are engaged in for religious reasons, or only because of the religious belief that they display.” Id. at 887.

${ }^{279}$ City of Boerne v. Flores, 521 U.S. 507, 514 (1997).

${ }^{280}$ Laws cannot have the "unconstitutional object of targeting religious beliefs and practices." Id. at 529.

${ }^{281}$ Cf. Church of Lukumi Babalu Aye v. City of Hileah, 508 U.S. 520, 531-32 (1993).

282 “[T] motivated action [which] involve[s] not the Free Exercise Clause alone, but the Free Exercise Clause in conjunction with other constitutional protections. . . .” Employment Division v. Smith, 494 U.S. 872, 881 (1990). These additional constitutional protections include, inter alia, freedoms of speech and press, see Cantwell v. Connecticut, 310 U.S. 296 (1940), and parent's rights to direct the education of their children, see Wisconsin v. Yoder, 406 U.S. 205 (1972). Employment Division v. Smith, 494 U.S. 872, 881-82 (1990). 
to internal church affairs. ${ }^{283}$ In EEOC v. Catholic University of America, ${ }^{284}$ for example, the D.C. Circuit held that there are two strands of Free Exercise analysis. First, statutes that “interfere[e] with a believer's ability to observe the commands or practices of his faith” are subject to Smith. ${ }^{285}$ In contrast, though, statutes that would "encroach[] on the ability of a church to manage its internal affairs" 286 fall outside of Smith and must survive strict scrutiny. A church, not an individual, can be relieved of laws of general applicability. ${ }^{287}$

Prohibiting the ministerial exception violates the Free Exercise Clause because government would be interfering with a religious organization's internal affairs. $^{288}$ Such a law would have more than an incidental effect on religious practices. $^{289}$ Religious education is a central purpose of many religious organizations and prohibiting them from discriminating in the hiring of ministerial

283 See, e.g., Combs v. Central Texas Annual Conference of the United Methodist Church, 173 F.3d 343, 349 (5th Cir. 1999). The internal church affair doctrine pre-dates Smith. In Kedroff v. St. Nicholas Cathedral of Russian Orthodox Church, 344 U.S. 94 (1952), the Supreme Court refused to resolve an internal church dispute on Free Exercise grounds. But, the Court has never ruled directly on the ministerial exception. Instead, lower courts have all held that the exception, as part of the internal church affairs doctrine, survives Smith.

${ }^{284}$ EEOC v. Catholic University of America, 83 F.3d 455 (D.C. Cir. 1996).

${ }^{285} I d$. at 460 .

${ }^{286} I d$.

287 “The ministerial exception is not invoked to protect the freedom of an individual to observe a particular command or practice of his church. Rather it is designed to protect the freedom of the church to select those who will carry out its religious mission.” EEOC v. Catholic University of America, 83 F. 3d 455, 462 (D.C. Cir. 1996) (emphasis added); Hyman v. City of Louisville, 132 F. Supp. 2d 528, 537-38 (W.D. Kent. 2001) (finding that a local civil rights code exempted religious organizations, but not religious individuals, for some kinds of employment discrimination).

288 "[C]hurches have a constitutionally protected interest in managing their own institutions free of government interference.” Douglas Laycock, Towards a General Theory of the Religion Clauses: The Case of Church Labor Relations and the Right of Church Autonomy, 81 CoLuM. L. REV. 1373, 1373 (1981).

${ }^{289}$ Church of Lukumi Babalu Aye v. City of Hialeah, 508 U.S. 520, 542-43 (1993). 
employees would hinder their ability to ensure that the school's religion teachers adhered to the religion's tenets. This would disrupt the ability of religious organizations to provide a religious education to both its voucher and non-voucher students. Additionally, revocation of the ministerial exception would force courts to evaluate religious doctrine in determining whether an applicant was qualified for the ministerial position, a clear violation of the Establishment Clause. ${ }^{290}$ As such, the Free Exercise Clause gives religious organizations the constitutional right to discriminate in the employment decisions they make regarding ministerial employees, including teachers of religious subjects.

Section IV.B. Local Civil Rights Codes, the Title VII Exemption, And the SMITH-HYBRID TEST

Non-ministerial employees would fall outside the internal church affairs doctrine and, therefore, be subject to a Smith analysis. Since antidiscrimination laws are generally applicable and are not targeted at religious practice, their enforcement against religious schools, at first blush, appears constitutional. Therefore, applying these statutes to religious schools does not seem to violate the Free Exercise Clause.

But if Congress attempted to curtail a religious school's ability to discriminate by rescinding the Title VII exemption, or if state and local governments sought to enforce civil rights codes that prohibit discrimination based on sexual orientation, more than just Free Exercise is involved - other fundamental rights may be implicated. ${ }^{291}$ To reconcile previous Free Exercise jurisprudence with the new Smith rule, the Court noted an exception: when Free Exercise and another constitutional right are simultaneously violated by a generally applicable, neutral

290 See supra pp. 40-41.

291 The Smith court recognized that some fundamental rights, such as the freedom to direct the education of one's children and freedom of speech, were likely candidates for Smith-Hybrid cases. Employment Division, Department of Human Resources of Oregon v. Smith, 494 U.S. 872, 881-82 (1990). 
law, the Sherbert standard applies. ${ }^{292}$ Commentators refer to these types of cases as "Smith-Hybrid" cases. ${ }^{293}$

The state clearly has an interest in ending employment discrimination. ${ }^{294}$ But that goal must be weighed against the burden placed on religious practice. There are two constitutional rights that be may implicated in applying antidiscrimination laws to non-ministerial employees of a religious school: the freedom of expressive association and the right of parents to direct their child's education. If a court concludes that either right is implicated along with the Free Exercise Clause, the state’s burden dramatically increases.

\section{Section IV.B.1. Free Exercise and Conduct-Based Discrimination}

State and local governments' civil-rights codes often abut the beliefs and practices of religious organizations. For example, laws that forbid discrimination based on sexual orientation conflict with the tenets of several major religions. ${ }^{295}$ Do religious organizations and their schools have a constitutional right to avoid the reach of these laws?

In the context of discussing religious organizations, the constitutional right that would provide the most obvious source of cover would be the Free Exercise

\footnotetext{
292 See Employment Division v. Smith, 494 U.S. 872, 882-84 (1990). “The only instances where a neutral, generally applicable law had failed to pass constitutional muster, the Smith Court noted, were cases in which other constitutional protections were at stake.” City of Boerne v. Flores, 521 U.S. 507, 513-514 (1997).

293 Employment Division v. Smith, 494 U.S. 872, 881-82 (1990); see also Watchtower Bible and Tract Soc'y of New York v. Village of Stratton, 536 U.S. 150, 160 n.8 (2002). For a summary of the debate regarding Smith-Hybrid cases, see Thomas C. Berg, Religious Liberty in America at the End of the Century, 16 J.L. \& RELIGION 187, 196 (2001).

${ }^{294}$ See, e.g., Scott M. Michelman, Faith-Based Initiatives, 39 HARV. J. ON LEGIS. 475, 496-98 (2002); Bruce N. Bagni, Discrimination in the Name of the Lord: A Critical Evaluation of Discrimination by Religious Organizations, 79 COLUM. L. REV. 1514 (1979).

295 See notes 53 and 57.
} 
Clause. But, following the Court's opinion in Smith, there is little chance that a stand-alone Free Exercise would succeed when challenging a state or local prohibition on employment discrimination. ${ }^{296}$ In most cases, state and local antidiscrimination laws are neutral, generally applicable, and do not target religion. ${ }^{297}$ Because the statute treats religious employers in the same way as other employers who may have their own belief structures, it is valid even if the effect on religion is not insubstantial. To succeed, religious schools must combine their Free Exercise concerns with infringement of another fundamental right to fall within the Smith-Hybrid carve-out. ${ }^{298}$ The combination of the two rights will subject the government regulation to a strict-scrutiny analysis and, thus, render it less likely to be found constitutional.

The strongest constitutional right that religious schools may pair with their Free Exercise concerns is the Freedom of Expressive Association. ${ }^{299}$ This right is seen as part of the First Amendment's Free Speech right in that "[t]he right to speak is often exercised most effectively by combining one's voice with the voice of others. "300 To maintain the clarity of their message, expressive organizations ${ }^{301}$ have

\footnotetext{
${ }^{296}$ There have been several (unsuccessful) cases where individuals have tried to make Free Exercise arguments regarding moral-code issues - one involving a pro-life doctor. See, e.g., Hyman v. City of Louisville, 132 F. Supp. 2d 528 (W.D. Kent. 2001). Generally, courts have found that local civilrights codes are generally applicable and do not infringe on any other fundamental right of the religious follower.

297 These laws prohibit discrimination by all employers, including religious organizations. They are designed to end a particular form of discrimination, usually based on sexual orientation.

${ }^{298}$ Employment Division v. Smith, 494 U.S. 872, 881-82 (1990).

299 The term "Expressive Association" has been used by the Supreme Court in Roberts v. United States Jaycees, 468 U.S. 609, 623 (1984) (finding that the Jaycees' expressive-association rights did not permit sex discrimination), Boy Scouts of America v. Dale, 530 U.S. 640, 649-650 (2000), and, more recently, Rumsfeld v. Forum for Academic and Institutional Rights, 547 U.S. 47, 68-70 (2006) (finding that law schools' expressive-association rights were not violated by a law requiring them to allow military recruiters on campus despite the recruiters' discriminatory hiring practices).

${ }^{300}$ Rumsfeld v. Forum for Academic \& Institutional Rights, 547 U.S. 47, 68 (2006).
} 
a constitutional right to restrict their membership, and especially their workforce, to only those who adhere to the group's beliefs and conduct themselves in a manner consistent with the organization's moral code. For instance, in Boy Scouts v. Dale, the Supreme Court held that the Boy Scouts' expressive-association rights permitted the group to expel an openly homosexual scout leader despite a New Jersey statute banning discrimination based on sexual orientation. ${ }^{302}$ In so holding, the Court said that to prohibit these decisions would force the organization "to accept members it does not desire.”303

It seems evident that the central purpose of religious organizations and their schools is to convey their religious message and teachings. The Archdiocese of Chicago, for instance, says that its "schools exist primarily to evangelize about the Good News of Jesus Christ and educate Catholic students for the Church's mission.”304 By requiring employees to conduct their personal lives in line with religious doctrine, religious schools communicate to their students the righteousness of those beliefs. ${ }^{305}$ All employees act as role models for a school's students. The Archdiocese of Chicago, like other Dioceses, views its "Catholic school principals and teachers as leaders, giv[ing] witness to Gospel living, spiritual and intellectual development, justice for all persons, and a quest for educational excellence.”306

\footnotetext{
301 These organizations do not necessarily have to be specifically religious. For example, the Boy Scouts are not a religious organization but their moral code is based on religion. But they do need to be organizations designed and operated to send a message.

${ }^{302}$ Boy Scouts of America v. Dale, 530 U.S. 640 (2000).

${ }^{303}$ Boy Scouts of America v. Dale, 530 U.S. 640, 648 (2000).

${ }^{304}$ Archdiocese of Chicago, Mission of Catholic Schools in the Archdiocese of Chicago, available at http://schools.archchicago.org/public/genesis.htm.

${ }^{305}$ Smith specifically includes "communicative activity" as a "constitutional protection" that, along with a Free Exercise claim, would "present ... a hybrid situation." Employment Division v. Smith, 494 U.S. 872, 882 (1990).

${ }^{306}$ Archdiocese of Chicago, Mission of Catholic Schools in the Archdiocese of Chicago, available at http://schools.archchicago.org/public/genesis.htm.
} 
Applying local, state, and federal antidiscrimination statutes that focus on employee conduct such as homosexuality or sex outside of marriage to religious schools would directly infringe on their Freedom of Expressive Association. If the school could not fire employees whose actions conflicted with the church's moral code, the school would be sending an implicit message to students that it endorses the activity. This result could not stand under Boy Scouts v. Dale, and, thus, would be unconstitutional when applied to religious schools.

\section{Section IV.B.2. Free Exercise and the Title VII Exemption}

Imagine that rather than trying to root out conduct-based discrimination, state and local officials wished to abrogate the Title VII exemption allowing religious organizations to discriminate based on religious affiliation. Because the Title VII exemption is a creature of federal making, such state and local attempts would be doomed to fail under the Supremacy Clause. But what if Congress sought to rescind the exemption? Would applying Title VII's prohibition against religious discrimination against religious schools offend the Constitution?

Once again, religious organizations may look to Expressive Association to bolster their Free Exercise claims and thereby attempt to force Congress to justify the rescission under the heavier burden of strict scrutiny. But unlike conduct-based discrimination, the religious organization's claims of expressive association will fall short since that right is based on speech and conduct rather than religious affiliation per se. As long as the school can require an employee to conform his or her actions to the religion's code of conduct, including requiring silence about his or her true religious faith, the school's religious message remains unadulterated. ${ }^{307}$ Whether the employee sincerely believes the message is not relevant. Because the Title VII

\footnotetext{
307 There may, however, be issues with participation in religious ceremonies by non-adherents. This would transform discrimination based on religious affiliation into discrimination based on conduct. A Catholic who refused to take Communion would face the same reaction from her employers as a nonCatholic who was religiously proscribed from taking Communion, if the school believed that universal participation in the sacrament was an integral part of the Church's message.
} 
exemption is not required for a Church to convey its religious message, revocation of the exemption would not trigger expressive association concerns. Some other fundamental right must be found.

One alternative right a religious school and its members may choose to combine with their Free Exercise claim is the parents fundamental right to "control the education and upbringing of one’s children.” ${ }^{308}$ This right was first recognized in a series of cases in the 1920s where state governments attempted to restrict students' educational opportunities. In Meyer v. Nebraska, the state law attempted to prohibit the teaching of any foreign language before high school. ${ }^{309}$ And, in Pierce v. Society of Sisters, the Supreme Court rejected an attempt by Oregon to eliminate all parochial schools. ${ }^{310}$ The Court has repeatedly acknowledged what is now referred to as the Meyer-Pierce right ${ }^{311}$ and has explained that the right includes "the inoculation of moral standards, religious beliefs, and elements of good citizenship., 312

Parents instill their children with their own religious beliefs and make choices to ensure that their children's education mirrors those beliefs. ${ }^{313}$ Persumably, parents send their children to religious schools to inculcate the church's message in their children. Any attempt by Congress to rescind the Title VII exemption and thereby explicitly prohibit discrimination based on religious affiliation could lead to dilution

\footnotetext{
${ }^{308}$ Fields v. Palmdale Sch. Dist., 427 F.3d 1197, 1204 (9th Cir. 2005).

${ }^{309}$ Meyer v. Nebraska, 262 U.S. 390 (1923).

${ }^{310}$ Pierce v. Society of Sisters, 268 U.S. 510 (1925).

${ }^{311}$ See, e.g., Meyer v. Nebraska, 262 U.S. 390 (1923); Pierce v. Society of Sisters, 268 U.S. 510, 53435 (1925). See also Wisconsin v. Yoder, 406 U.S. 205, 214, 233-34 (1972); Norwood v. Harrison, 413 U.S. 455, 461 (1973); Troxel v. Granville, 530 U.S. 57, 66 (2000).

${ }^{312}$ Yoder, 406 U.S. at 233. "Pierce stands as a charter of the rights or parents to direct the religious upbringing of their children.” Id.

${ }^{313}$ Wisconsin v. Yoder, 406 U.S. 205, 233-34 (1972). See also Employment Division v. Smith, 494 U.S. 872, 881-82 (1990).
} 
of that message. One could argue that denying schools that participate in a schoolvoucher program the Title VII exemption infringes on the fundamental rights of parents because religious schools could not ensure the quality and thoroughness of the religious education. ${ }^{314}$ Absent the religious employment-discrimination exceptions, schools would not be able to ensure that their employees were devout followers of the faith or conduct their lives as role models for students.

Smith specifically mentions "parental right[s]" as "constitutional protections" that, along with a Free Exercise claim, could "present . . . a hybrid situation."315 If the schools cannot discriminate on the basis of religion, the prohibition would thwart the religious activities of parents and denies them their fundamental right to direct the education of their children. The combination of the Free Exercise right and the Meyer-Pierce right could present a Smith-Hybrid case.

But a parent's Meyer-Pierce right to control his child's upbringing is not limitless. $^{316}$ For example, the right does not give parents the authority to dictate what is taught in public schools. ${ }^{317}$ Similarly, Meyer-Pierce does not include the right to have one's children educated in segregated schools. ${ }^{318}$ It seems likely,

314 There may be standing issues involved here. The constitutional right to guide one's children's education belongs to parents and the Free Exercise right belongs to the religious school. Denying the Title VII exemption to religious schools, however, would also burden parents who want access to the religious education for their children, and thus, have Free Exercise implications for the parents and students. In Freedom from Religion Found., Inc., v. McCallum, a district court allowed a faith-based provider to assert standing on behalf of program participants. 179 F. Supp. 2d 950, 965-66 (2002) (finding that where there is a "close relationship" between the Free Exercise claimant and the party with the other constitutional claim, "a party that has suffered an injury has standing to raise a claim for third parties not before the court) (citing ERWIN CHEMERINSKY, FEDERAL JURISDICTION § 2.3.4 (3d ed.1999); Singleton v. Wulff, 428 U.S. 106 (1976); Craig v. Boren, 429 U.S. 190 (1976). Religious parents seeking a religious education for their children may have the necessary "close relationship" with the religious school it to establish standing in a case challenging the denial of the Title VII exemption.

${ }^{315}$ Employment Division v. Smith, 494 U.S. 872, 881-82 (1990).

${ }^{316}$ See Prince v. Massachusetts, 321 U.S. 158, 166 (1944);

317 See Fields v. Palmdale School District, 447 F.3d 1187, 1190 (9th Cir. 2005); Blau v. Fort Thomas Public School District, 401 F.3d 381, 395 (6th Cir. 2005).

${ }^{318}$ Runyon v. McCrary, 427 U.S. 160, 177 (1976). 
therefore, if adjudicated, the Meyer-Pierce right would not give parents the right to have their children educated in a school where all the employees were only of one religion. Because the Meyer-Pierce right does not apply, its pairing with the Free Exercise Clause would not qualify for the Smith-Hybrid carve-out and any suit following the rescission of the Title VII exemption based on this argument would likely fail. ${ }^{319}$

\section{PART V: Conditioning PARTicipation On Relinquishment}

The Establishment Clause analysis shows that religious schools in voucher programs can fire or refuse to hire employees based on the ministerial exception, the Title VII exemption, or the employee's conduct. ${ }^{320}$ And, the Free Exercise Clause creates a broad constitutional right to fire ministerial employees and a more limited right to fire employees when they act as moral exemplars and their conduct deviates from the church's code of conduct. ${ }^{321}$ Lastly, the government can institute statutory exemptions from employment-discrimination laws and, in some cases, must do so to avoid constitutional violations.

Imagine the state of Massafornia implemented a school-voucher program in response to public discontent with the quality of its public-education system. Because the large majority of private schools in the state are religious schools, they

\footnotetext{
319 The rescission of the Title VII exemption would not be so drastic for religious schools. Since the religious message is protected by conduct-based discrimination and the ministerial exception, there is little left for the Title VII exemption to protect. For example, in Curay-Cramer v. The Ursuline Academy of Wilmington, Delaware, 450 F.3d 130 (3d Cir. 2006), a Catholic teacher was fired after adding her name to an advertisement in support of abortion rights. The school had publicly stated that she was fired because of her "serious disagreement with a basic tenet of religious teaching," id. at 934, and the court applied the ministerial exception. Even without the Title VII exemption, the firing was not illegal.

${ }^{320}$ See supra Parts II and III.

${ }^{321}$ See supra Part IV.
} 
were included as options for students receiving vouchers. Lawmakers were concerned, however, that these religious schools would attempt to discriminate in their hiring practices. To curb this behavior, the school-voucher statute stated that, as a condition of participation, "no school may discriminate based on race, sex, ethnicity, religion, sexual orientation, gender identity, or family structure, for any position.”

The Church School agreed to participate in the program and began accepting students. One of the school's teachers, Meredith Smith, had led the School's worship services but they decided to terminate her employment after Ms. Smith wrote an editorial in the local newspaper supporting legislation to allow gay couples to adopt children. In the piece, Ms. Smith identified herself as a lesbian. The Church, when confronting Ms. Smith about the editorial, also discovered that Ms. Smith was an atheist. After her firing, Ms. Smith approached the Massafornia Equal Employment Opportunity Commission to contest her discharge. Arguably, the Church school could defend the firing on the ministerial exception, the Title VII exemption, or conduct-based firings. Ms. Smith responds that the School waived any rights to discriminate that they otherwise would have had by agreeing to participate in the school-voucher program.

But could the government, whether federal or state, condition participation by religious schools in a voucher program on relinquishment or waiver of these constitutional rights and statutory employment-discrimination exemptions? Part V. addresses this question first in Section V.A. with respect to the ministerial exception and then in Section V.B. in the context of the unconstitutional conditions doctrine.

Section V.A: Conditioning Participation on WAiver of the Ministerial EXCEPTION

There is little need to conduct a thorough "unconstitutional conditions" analysis with respect to the ministerial exception. As this Article has stated 
elsewhere, the very act of adjudicating an employment dispute between a church and its minister would violate the Constitution's Religion Clauses. Such a case would be akin to a Shelley $v$. Kraemer-type ${ }^{322}$ situation where the court's very involvement in the case creates a constitutional violation. ${ }^{323}$ When faced with a ministerialexception case, even if a religious school had arguably waived its constitutional right to discriminate when hiring its ministers, the court's inquiry must end once the religious organization establishes that the plaintiff served a ministerial function and that the defendant is a religious organization. "[T]he ministerial relationship lies so close to the heart of the church that it would offend the Free Exercise Clause simply to require the church to articulate a religious justification for its personnel decisions."324

Any attempt by government to condition participation in a school voucher program on relinquishment of this right would likewise be unconstitutional. ${ }^{325}$ As a result, essentially, the ministerial exception is not subject to waiver or estoppel. A religious organization, such as a school interested in participating in a voucher program, could "relinquish” its ministerial-exception rights but such a waiver would have no effect.

\section{SECTION V.B: The UnConstitutional Conditions DoctRine}

\footnotetext{
322 Shelley v. Kraemer, 334 U.S. 1 (1948) (holding that state enforcement of private, raciallyrestrictive covenants would constitute state action and, therefore, violate the Fourteenth Amendment).

${ }^{323}$ Some courts have held that the ministerial exception is not a jurisdictional bar to adjudication, but instead is a defense that challenges the sufficiency of the plaintiff's claim. See, e.g., Petruska v. Gannon Univ., 462 F.3d 294, 302 (3d Cir. 2006); Elvig v. Calvin Presbyterian Church, 375 F.3d 951, 955 (9th Cir. 2004); Bryce v. Episcopal Church in the Diocese of Colorado, 289 F.3d 648, 654 (10th Cir. 2002).

${ }^{324}$ Bollard v. California Province of the Society of Jesus, 196 F.3d 940, 946 (9th Cir. 1999).

325 Tomic v. Catholic Diocese of Peoria, 442 F.3d 1036, 1042 (7th Cir. 2006); Minker v. Baltimore Annual Conference of United Methodist Church, 894 F.2d 1354, 1356-57 (D.C. Cir. 1990).
} 
From the case law, it is clear that government may, in some circumstances, use its spending power to indirectly achieve ends that it would be constitutionally prohibited from pursuing directly. ${ }^{326}$ For example, in South Dakota v. Dole, the Supreme Court upheld a federal highway funding grant conditioned on South Dakota adopting a minimum drinking age of twenty-one despite the fact that Congress had no constitutional authority to mandate the state's legal drinking age. ${ }^{327}$ As Chief Justice Rehnquist said, “objectives not thought to be within Article I's 'enumerated legislative fields' ... may nevertheless be attained through the use of the spending power and the conditional grant of federal funds.”328

Congress's use of its Spending Clause power to achieve otherwise unattainable ends is not limitless. "An unconstitutional condition question is said to emerge whenever government conditions a benefit it is not obligated to provide on waiver of a constitutional right." "329 While "the Government has no constitutional duty to subsidize an activity merely because the activity is constitutionally protected, ${ }^{330}$ not all conditions placed upon constitutional activity in exchange for government dollars are constitutional. ${ }^{331}$

\footnotetext{
${ }^{326}$ See Kathleen M. Sullivan, Unconstitutional Conditions, 102 HARV. L. REV. 1413, 1415 (1989); Sarah Waszmer, Note, Taking It Out of Neutral: The Application of Locke's Substantial Interest Test to the School Voucher Debate, 62 WASH. \& LEE L. REV. 1271, 1296 (2005).

327 South Dakota v. Dole, 483 U.S. 203 (1987).

${ }^{328}$ South Dakota v. Dole, 483 U.S. 203, 207 (1987).

329 Mitchell N. Berman, Coercion Without Baselines: Unconstitutional Conditions in Three Dimensions, 90 GEO. L.J. 1, 8 (2001).

${ }^{330}$ Rust v. Sullivan, 500 U.S. 173, 201 (1991).

331 See Nollan v. Calif. Coastal Commission, 483 U.S. 825, 837 (1987); Connick v. Myers, 461 U.S. 138, 142 (1983) ("a State cannot condition public employment on a basis that infringes the employee's constitutionally protected interest in freedom of expression”); Sherbert v. Verner, 374 U.S. 398, 404 (1963) (holding unconstitutional a statute that forced the plaintiff "to choose between following the precepts of her religion and forfeiting benefits, on the one hand, and abandoning one of the precepts of her religion in order to accept work, on the other”).
} 
The test for which conditions are permissible and which are unconstitutional, however, remains profoundly unclear. ${ }^{332}$ "Although it has a long history, the ‘unconstitutional conditions' doctrine has for just as long suffered from notoriously inconsistent application; it has never been an overarching principle of constitutional law that operates with equal force regardless of the nature of the rights and powers in question." ${ }^{333}$ But, according to one of the more recent Court pronouncements on the doctrine, "the government may not require a person to give up a constitutional right ... in exchange for a discretionary benefit conferred by the government where the benefit sought has little or no relationship” to the condition. ${ }^{334}$ This standard can be broken down into three parts. The first question asks whether government is providing a discretionary or a mandatory benefit. If the benefit is discretionary, the analysis then asks if the condition implicates a constitutional right. If so, there must be a substantial relationship or an "essential nexus" between the benefit sought and the waived right in order for the condition to stand.

\footnotetext{
332 Thomas C. Berg, Vouchers and Religious Schools: The New Constitutional Questions, 72 U. CIN. L. REv. 151 (2003); Mitchell N. Berman, Coercion Without Baselines: Unconstitutional Conditions in Three Dimensions, 90 GEO. L.J. 1, 3 (2001) ("The persistent challenge ... has been to articulate some coherent or at least intelligible principles or tests.”); David Freeman Engstrom, Drawing Lines Between Chevron and Pennhurst: A Functional Analysis of the Spending Power, Federalism, and the Administrative State, 82 TEXAS L. REV. 1197, 1200 (2004) ("One problem is that the governing test set forth in South Dakota v. Dole does not provide much in the way of a doctrinal foothold.”); Kathleen M. Sullivan, Unconstitutional Conditions, 102 HARV. L. REv. 1413, 1415 (1989); Cass Sunstein, Why the Unconstitutional Conditions Doctrine is an Anachronism, 70 B.U. L. REV. 593, 620 (1990) ("too crude and too general to provide help in contested cases"); Sarah Waszmer, Note, Taking It Out of Neutral: The Application of Locke's Substantial Interest Test to the School Voucher Debate, 62 WASH. \& LEE L. REV. 1271, 1301 (2005) ("A review of the unconstitutional conditions cases shows that the Court has no firm doctrinal basis for its decisions.").

333 Dolan v. City of Tigard, 512 U.S. 374, 407 n. 12 (1994) (Stevens, J., dissenting) (citations omitted).

${ }^{334}$ Dolan v. City of Tigard, 512 U.S. 374, 385 (1994). Justice Stevens, in his dissent, disagreed with the Court's contention that the unconstitutional conditions doctrine was "well settled." Dolan v. City of Tigard, 512 U.S. 374, 407 n. 12 (1994) (Stevens, J., dissenting) (stating that it is "quite clear that the Court is really writing on a clean slate rather than merely applying 'well-settled' doctrine).
} 


\section{Section V.B.1: Discretionary Government Benefit}

It is by no means clear that a school's participation in a voucher program is a discretionary government benefit. Specifically, there are two questions that must be answered. First, does participation in the voucher program amount to a benefit to the school? Second, even if it is a benefit, is it a discretionary one?

One could argue that children in the program and their parents, not the church school, are the true beneficiaries of the government program. In a typical Unconstitutional Conditions case, the recipient of government funds is asked to waive his own constitutional rights. Here, though, the government is trying to condition the school's participation on relinquishment of its right rather than on a parent's. If no benefit accrues to the school itself, the analysis collapses to whether the government can constitutionally demand the waiver while giving nothing in return. In other words, we return to the analysis in Part IV with government attempting to curtail a religious school's constitutional rights to discriminate directly rather than indirectly through a condition. ${ }^{335}$

Proponents of conditioning would argue that religious schools in voucher programs are receiving a benefit, even if they concede that program funds reach the schools only through the independent decision making of parents. Instead of receiving government funding in exchange for the waiver of rights, religious schools receive a benefit merely by inclusion in the program. Students who could otherwise not afford to attend a religious school can enroll when tuition is subsidized. Religious schools benefit through these increased enrollments and the concordant increased community presence.

Even if participation is a sufficient benefit to trigger the Unconstitutional Conditions analysis, allowing a religious school to participate may not be a

\footnotetext{
${ }^{335}$ See supra Part IV.
} 
discretionary decision. ${ }^{336}$ Generally, voucher statutes set out objective criteria that each school must satisfy before being included in a program. Such criteria include adherence to local education requirements, submitting to financial audits, ${ }^{337}$ conducting routine educational assessments of voucher students, ${ }^{338}$ and monthly reporting of voucher students' enrollment. ${ }^{339}$ Cleveland's school voucher program commands, for example, that the "state superintendent shall register any school that meets” objective criteria such being located in the Cleveland program's district and "state minimum standards for chartered nonpublic schools." 340 The "shall” language suggests that the inclusion of a school in the program is not a discretionary decision for the state superintendent.

But other "objective" criteria may require schools to waive their antidiscrimination exemptions, ${ }^{341}$ including those mandated by the Free Exercise Clause. In the Cleveland program, for example, one requirement for inclusion is that a religious "school does not discriminate on the basis of race, religion, or ethnic

\footnotetext{
${ }^{336}$ Based on recent case law and commentary, a jurisdiction can authorize and fund a school-voucher program but exclude all religious schools. See Locke v. Davey, 540 U.S. 712 (2004) (upholding a Washington program that prohibited higher-education tuition vouchers for religious instruction); Anderson v. Town of Durham, 895 A.2d 944, 952 (Me. 2006) (upholding Maine’s school-voucher program that excludes religious schools); Thomas [C.] Berg, Vouchers and Religious Schools: The New Constitutional Questions, 71 U. CIN. L. REV. 151 (2003) (pre-Locke and Anderson analysis); Thomas C. Berg \& Douglas Laycock, The Funding of Religious Institutions in Light of Locke v. Davey: The Mistakes in Locke v. Davey and the Future of State Payments for Services Provided by Religious Institutions, 40 TULSA L. REV. 227 (2004).

${ }^{337}$ UTAH CODE ANN. §§ 53A-1A-705 (1)(b) (2007).

${ }^{338}$ UTAH CODE ANN. §§ 53A-1A-705 (1)(f) (2007).

339 OHIo Rev. Code ANN. §§ 3313.979 (A)(1) (2008) (Cleveland program).

${ }^{340}$ OHIo Rev. Code AnN. §§ 3313.976 (A) (2008).

${ }^{341}$ For example, Cleveland's program does not permit participation by schools that "discriminate on the basis of race, religion, or ethnic background.” OHIo REv. CODE ANN. §§ 3313.976 (A) (4) (2008). Cf. UTAH CODE ANN. §§ 53A-1A-705 (1)(c) (2007) (only requiring compliance with the antidiscrimination provisions of 42 U.S.C. $\S 2000 \mathrm{~d}$ which prohibits discrimination against those receiving benefits from a government-funded programs).
} 
background."342 It is within the superintendent's discretion to assess whether a school has met this criterion. Because the superintendent could include one religious school that uses its antidiscrimination exemptions while excluding another, the benefit that schools receive is a discretionary one.

\section{Section V.B.2: Constitutional Rights Implicated}

Assuming that a religious school's participation in a school-voucher program is a discretionary government benefit, the next step in an Unconstitutional Conditions analysis asks whether a constitutional right is implicated. If government conditions the receipt of a discretionary benefit on the relinquishment of a privilege rather than a constitutional right, no constitutional problem exists. ${ }^{343}$

Section IV.B.2. demonstrated that the Title VII exemption for religious affiliation discrimination does not rise to the level of a constitutional right. While the exemption is permitted by the Establishment Clause, the Free Exercise Clause does not mandate it. As such, requiring a religious school to waive their statutory right to discriminate based on religious affiliation would not be an unconstitutional condition at first glance.

But in the few cases that have addressed waiver of the Title VII exemption, courts have held that it is subject to waiver or estoppels in only a narrow circumstance: when federal monies directly and completely funded specific positions within a church organization. ${ }^{344}$ The waiver was valid because the federal

\footnotetext{
342 OHIO REV. CODE ANN. §§ 3313.976 (A) (4) (2008).

343 An additional issue may exist as to whether the waiver of the right was made knowingly and voluntarily. See South Dakota v. Dole, 483 U.S. 203, 207 (1987); Brady v. United States, 397 U.S. 742, 748 (1970) ("Waivers of constitutional rights not only must be voluntary but must be knowing, intelligent acts done with sufficient awareness of the relevant circumstances and likely consequences.”). The antidiscrimination restrictions in the various state statutes authorizing schoolvoucher programs may not meet this standard. See note 341. Courts may decline to apply these conditions rather than to address the potential federalism issue.

344 Dodge v. Salvation Army, No. S88-0353(R), 1989 U.S. Dist. LEXIS 4797 (S.D. Miss. Jan. 10, 1989).
} 
government conditions the receipt of federal funds on the relinquishment of the federal right. Congress could rescind the Title VII exemption and, because it is not constitutionally mandated, achieve the same ends as conditioning participation on relinquishment of the exemption. What they may do directly, they may also accomplish indirectly. The District of Columbia’s Opportunity Scholarship Program is a creature of Congress. Since the same legislative body that granted the Title VII exemption is the one now seeking waiver, Congress can condition participation in D.C.'s voucher program on relinquishment of the exemption. No further Unconstitutional Conditions analysis is necessary.

But could a state condition participation in its school-voucher program on relinquishment of a federal, but not constitutionally-mandated, right? Permitting a state to interfere with federally granted rights could raise constitutional concerns. ${ }^{345}$ Under the Supremacy Clause, the rights granted by the higher sovereign trump the state's efforts. From the state's perspective, the federally granted right is the equivalent of a constitutional one. With the exception of the District of Columbia's Opportunity Scholarship Program, state and local monies fund existing schoolvoucher programs, not federal dollars. Therefore, no state or locality would be permitted to condition participation in its program on a waiver of the federal Title VII exemption unless the condition satisfies the remainder of the Unconstitutional Conditions doctrine.

While from a state's perspective the Title VII exemption acts like a constitutional right, the combination of the Free Exercise Clause and Freedom of Expressive Association, in the context of conduct-based firings, is a full-fledged

\footnotetext{
${ }^{345}$ Nicholls v. Brookdale Univ. Hospital Medical Center, No. 03-CV-6233 (JBW), 2004 U.S. Dist. LEXIS 12816, at *18 (E.D.N.Y. July 9, 2004); Collette v. St. Luke’s Roosevelt Hospital, 132 F. Supp. 2d 256, 265 (S.D.N.Y. 2001) ("an effort by New York to condition a state law right on the waiver of arguably unrelated federal rights would raise serious constitutional questions") (emphasis in original). Cf. Harrison v. St. Louis \& San Francisco R.R., 232 U.S. 318, 328 (1914) ("the judicial power of the United States ... is a power wholly independent of state action and which therefore the several States may not by any exertion of authority in any form, directly or indirectly, destroy, abridge, limit or render inefficacious").
} 
constitutional right that acts to constrain both state and federal governments alike. ${ }^{346}$ As a constitutional right is implicated in the hypothetical waiver demanded by the state in exchange for inclusion in the program, the Unconstitutional Conditions analysis must continue to the next step: Essential Nexus.

\section{Section V.B.3: Essential Nexus}

The final step in an Unconstitutional Conditions analysis requires that the asserted condition and the implicated constitutional right share an essential nexus. ${ }^{347}$ But if the person asked to agree to the condition is fully apprised of what he is relinquishing and the exchange is beneficial to both him and the state, the would-be conditionee should be free to waive his rights regardless of the germaneness of the condition. He has implicitly found that the relinquished right is not worth as much to him as the newly gained benefit.

On the other hand, there is a lingering concern that

Leviathan, swollen with tax dollars, will buy up people's liberty. Moved not by redistributive frenzy but by the desire to expand the sphere of state power by exerting moral and social control that it could not constitutionally impose directly, the state will buy people out to control their decision making. ${ }^{348}$

Implicitly, two fears stem from unfettered opportunities to bargain away individual rights: first, that individuals will waive their rights for too low a price, and second, that broad application of a constitutional right confers societal benefits that individuals will not take into account. By requiring an essential nexus between the

\footnotetext{
${ }^{346}$ See supra Section IV.B.1.

${ }^{347}$ Nollan v. California Coastal Commission, 483 U.S. 825, 836-37 (1987) (explaining the essential nexus rational); Dolan v. City of Tigard, 512 U.S. 374, 386-391 (1994) (holding that even where an essential nexus exists, the condition and the benefit received must have some "rough proportionality”).

${ }^{348}$ Kathleen Sullivan, Unconstitutional Conditions, 102 HARV. L. REV. 1415, 1494 (1989) (describing Charles Reich, The New Property, 73 YALE L.J. 733 (1964)).
} 
program's purpose and the implicated constitutional right, we tame Leviathan where no such connection exists but still allow informed individuals to waive their rights when it does. In other words, if a "condition ... utterly fails to further the end advanced as the justification” for the program, it is unconstitutional. ${ }^{349}$

As seen in the previous Section, two scenarios present situations where conditioning participation in a school-voucher program on a religious school's waiver of its statutory and constitutional rights to discriminate requires an essential nexus: the waiver of the Title VII exemption in a state-run program and the relinquishment of the constitutional right to discriminate against certain employees based on their conduct. To determine if this "essential nexus" exists, we must compare the purpose of the school-voucher program with the rights to be waived.

While eliminating, correcting, or punishing the societal ills created by employment discrimination is a legitimate state purpose, it is not related to the school-voucher program whose obvious purpose is to provide increased educational opportunities for children. Requiring religious schools to forgo their Title VII exemption or their constitutional right to discriminate against employees based on conduct does nothing to advance the program's objectives. In fact, it may hinder them if attempted enforcement or threats of enforcement dissuade religious schools from participating in the programs in the first place. In contrast, conditions in voucher statutes that prohibit discrimination against students would likely exhibit the essential nexus to the voucher program since restricting access to educational opportunities would impede the voucher program’s goals. But because no "essential nexus” exists between state-demanded conditions on certain types of otherwise permissible employment discrimination and their voucher programs, those conditions are unconstitutional and unenforceable.

\footnotetext{
${ }^{349}$ Nollan v. California Coastal Commission, 483 U.S. 825, 837 (1987).
} 


\section{CONCLUSION}

This Article considered whether the employment practices of religious schools participating in a voucher program raises both Establishment Clause and Free Exercise Clause issues. To assess an Establishment Clause challenge to accommodations such as exemptions from federal, state, and local antidiscrimination laws, the haphazardly applied Lemon test is ill-fitting and unworkable. This Article suggested a new, more coherent test that the Supreme Court should adopt. First, the success of a religious school in teaching its religious tenets requires government noninterference in activities fundamental to the religious mission. In other words, "let religion be religious." Second, allowing all religious schools to participate in voucher programs and use the employment antidiscrimination exceptions demonstrates the government's neutrality among religions and ensures that government is not using its powers to favor one religion over another. Third, any federal or state money that reaches religious schools that practice employment discrimination arrives there "only as a result of the private decision of individual parents. ${ }^{\text {} 350}$ The government is not forcing children to attend the discriminating schools, and, as a result, no reasonable observer could view the antidiscrimination law exceptions as government endorsement of the religious organization's actions specifically or religion in general. Lastly, without exemptions from antidiscrimination laws, government could become excessively entangled with religious organizations in order to ferret out unlawful employment actions.

While the Establishment Clause merely permits exceptions from antidiscrimination laws for religious schools in voucher programs, the Free Exercise Clause prohibits state enforcement of antidiscrimination statutes where exceptions are absent. The ministerial exception allows all kinds of employment discrimination for certain key jobs because the Free Exercise Clause requires governmental respect

${ }^{350}$ Zelman v. Simmons-Harris, 536 U.S. 639, 652 (2002) (quoting Zobrest v. Catalina Foothills Sch. Dist., 509 U.S. 1, 10 (1993)). 
for a religious organization's internal structure. Any investigation into a church's employment decision making would itself create a constitutional violation. With respect to non-ministerial positions, though, government can and should take a closer look. Employment discrimination justified by concerns about the integrity of the religious message should be permitted because of the associational freedom enjoyed by all expressive associations, including religious schools. This argument, however, falters when examining the Title VII exemption for discrimination based on religion. There is no Free Exercise rationale justifying elevating the Title VII exemption to a constitutionally-mandated right. If a religious organization's non-ministerial employees conduct themselves in accord with the religious message, the organization's ability to convey its message has not been damaged. Religious affiliation is not a badge that either reinforces or detracts from that message and, as such, does not inform either the church's associational rights or a parent's right to direct his child's education.

While the Free Exercise Clause would prohibit states from enforcing antidiscrimination laws against some employees in particular circumstances, states may attempt to instead condition participation in a school-voucher program on voluntary waiver of religious schools' rights to discriminate. While state governments have expanded powers to restrict activities using conditions in areas where they would be prohibited from legislating outright, there are limits based on the Supreme Court's Unconstitutional Conditions doctrine. The analysis, however, demonstrates that any conditions relinquishing a religious school's right to discriminate in hiring ministerial employees, their right to enforce their federalgranted right to discriminate with respect to all employees based on religious affiliation in a state voucher program, and their constitutional right to discriminate based on conduct for some employees, would fail this test and would be unconstitutional. While states are, of course, free to put such conditions into a voucher programs statutory language, as several have, these conditions are essentially empty unenforceable promises. 